IZA DP No. 6275

Nice Guys Finish Last:

Are People with Higher Tax Morale Taxed More Heavily?

Philipp Doerrenberg

Denvil Duncan

Clemens Fuest

Andreas Peichl

January 2012 


\title{
Nice Guys Finish Last: Are People with Higher Tax Morale Taxed More Heavily?
}

\author{
Philipp Doerrenberg \\ CGS, University of Cologne and IZA \\ Denvil Duncan \\ Indiana University and IZA \\ Clemens Fuest \\ University of Oxford, University of Cologne, CESifo and IZA \\ Andreas Peichl \\ IZA, University of Cologne, ISER and CESifo
}
Discussion Paper No. 6275
January 2012

IZA

P.O. Box 7240

53072 Bonn

Germany

Phone: $+49-228-3894-0$

Fax: +49-228-3894-180

E-mail: iza@iza.org

\begin{abstract}
Any opinions expressed here are those of the author(s) and not those of IZA. Research published in this series may include views on policy, but the institute itself takes no institutional policy positions.

The Institute for the Study of Labor (IZA) in Bonn is a local and virtual international research center and a place of communication between science, politics and business. IZA is an independent nonprofit organization supported by Deutsche Post Foundation. The center is associated with the University of Bonn and offers a stimulating research environment through its international network, workshops and conferences, data service, project support, research visits and doctoral program. IZA engages in (i) original and internationally competitive research in all fields of labor economics, (ii) development of policy concepts, and (iii) dissemination of research results and concepts to the interested public.
\end{abstract}

IZA Discussion Papers often represent preliminary work and are circulated to encourage discussion. Citation of such a paper should account for its provisional character. A revised version may be available directly from the author. 


\section{ABSTRACT \\ Nice Guys Finish Last: Are People with Higher Tax Morale Taxed More Heavily?*}

This paper is the first to provide evidence of efficient taxation of groups with heterogeneous levels of 'tax morale'. We set up an optimal income tax model where high tax morale implies a high subjective cost of evading taxes. The model predicts that 'nice guys finish last': groups with higher tax morale will be taxed more heavily, simply because taxing them is less costly. Based on unique cross-country micro data and an IV approach to rule out reverse causality, we find empirical support for this hypothesis. Income groups with high tax morale systematically face higher average and marginal tax rates.

JEL Classification: H2, H3, D7

Keywords: tax morale, tax compliance, optimal taxation, political economy

Corresponding author:

Andreas Peichl

IZA

P.O. Box 7240

53072 Bonn

Germany

E-mail: peichl@iza.org

\footnotetext{
* Andreas Peichl is grateful for financial support from Deutsche Forschungsgemeinschaft DFG (PE1675). We are grateful to Klara Sabirianova-Peter for providing us with tax rate data from the World Tax Indicators. We would like to thank Oleg Badunenko, Felix Bierbrauer, Dan Hamermesh, Bradley Heim, Stephen Jenkins, Jorge Luis Martinez, Nico Pestel, Andrew Oswald, Salmai Qari, Justin Ross, Sebastian Siegloch, Andràs Simonovits, Caroline Weber, Jeff Wooldridge and participants of the IIPF 2011 (Ann Arbor), shadow2011 (Münster) and CESifo Political Economy (Dresden) conferences, as well as seminars in Bonn, Cologne, and Uppsala for helpful comments and suggestions. The usual disclaimer applies.
} 


\section{Introduction}

Tax morale ${ }^{1}$ - the intrinsic motivation to honestly pay taxes - is widely seen as advantageous for an economy because it reduces the cost of financing the public sector. Therefore, a large part of the academic and political debate focuses on the impact of institutions and policies on tax morale and on ways of improving it. This paper takes a different perspective and explores whether differences in tax morale across different groups of taxpayers within and across countries affect the tax burden imposed on these groups. Our main hypothesis is that groups with a high level of tax morale are taxed more heavily because taxing them creates smaller distortions. Using unique cross-country micro data and an Instrumental Variable (IV) approach, we provide robust evidence supporting our hypothesis.

The theoretical basis of our approach is straightforward. We start from the observation that different groups of individuals within one country as well as across countries can have different levels of tax morale. If the absolute amount of tax paid by a particular group of taxpayers is given, a high level of tax morale will imply that the tax base is large, so that tax rates can be low. This is advantageous because tax distortions of economic activity are smaller and tax enforcement and administration costs are lower than in cases where tax morale is low. It pays to have a high level of tax morale in such a world. However, if the tax revenue raised from particular groups of taxpayers is not given, groups with a high level of tax morale may end up paying higher taxes than groups with low tax morale. The reason is that a high level of tax morale reduces the cost of taxation, since groups with low tax morale respond to increases in taxation by evading more, relative to high morale groups.

We set up a simple model of optimal taxation, where the government maximizes an objective function in which each group of taxpayers has a given weight. The weight may depend on income, political influence, or other factors, but is unrelated to tax morale. Tax morale is introduced by assuming that different groups of taxpayers face different subjective costs of evading taxes. In this model, the government will systematically impose higher tax rates on groups with higher tax morale because taxing them causes smaller distortions. Our theoretical analysis thus yields the hypothesis that 'nice guys finish last': groups with high tax morale are 'punished' through the tax system because governments tax these groups more heavily.

We test our hypothesis using data from the World Value Survey (WVS), the

\footnotetext{
${ }^{1}$ The term 'tax morale' might be misleading and 'tax honesty' or 'tax ethics' might be more appropriate. However, it is the terminology used in the literature. Therein, tax morale is typically defined as 'the intrinsic motivation to pay taxes which arises from the moral obligation to pay taxes as a contribution to society' (e.g., Schwartz and Orleans 1967; Cummings et al. 2009).
} 
European Values Survey (EVS), and detailed income tax data from the World Tax Indicators Database (WTI) (Sabirianova-Peter et al. 2010). Combining these sources allows us to construct a unique micro dataset with all the necessary information in order to test the hypothesis. The WVS data allows us to observe levels of tax morale for different income groups in different countries, as well as various control variables. We then use the WTI database to compute average and marginal tax rates for the different income groups. Using an IV approach in order to rule out problems of reverse causality, we find that the data confirm our hypothesis: groups with higher levels of tax morale systematically face higher average and marginal tax rates. Results are robust to various specification checks.

To the best of our knowledge, this is the first paper to investigate whether differences in tax morale affect the distribution of the tax burden across different groups of taxpayers. The early literature on tax evasion and compliance models tax evasion essentially as a lottery, where individuals face a simple problem of expected utility maximization. This approach has been criticized for failing to explain why taxpayers seem to pay taxes even in situations where detection is unlikely and penalties are low (Slemrod and Yitzhaki 2002; Frey and Feld 2002; Torgler 2002). ${ }^{2}$ In light of these findings, recent research has put a lot of emphasis on tax morale as a major determinant of individuals' responsiveness to taxes (Andreoni et al. 1998; Torgler 2007). Several studies have shown that tax morale is indeed negatively correlated with tax evasion and the size of the shadow economy (Erard and Feinstein 1994; Torgler and Schneider 2009; Halla 2010).

These findings suggest that the prevailing level of tax morale is an important determinant of the government's ability to raise taxes and the cost of doing so (Feld and Frey 2007). Therefore, many scholars argue that policy makers should design tax systems and broader political institutions so as to preserve and improve tax morale. ${ }^{3}$ While these studies focus on the impact of policy and institutions on tax morale, this paper takes a different perspective by asking whether policymakers exploit the fact that their citizens have different levels of tax morale when setting tax rates. In other words, we take the level of tax morale as given and ask how tax morale affects the tax burden governments impose on different groups of taxpayers. ${ }^{4}$

\footnotetext{
${ }^{2}$ The standard theory of tax compliance models taxpayer behavior as a problem of expected utility maximization (Allingham and Sandmo 1972; Yitzhaki 1974; Sandmo 1981).

${ }^{3}$ For instance, Doerrenberg and Peichl (2011) show that higher tax progressivity is associated with higher tax morale. Torgler (2007) provides an extensive overview of the literature on the determinants of tax morale. Note that the evidence on the relationship between tax morale and income is mixed (see also footnote 17).

${ }^{4}$ Qari et al. (2011) show that countries with higher levels of patriotism typically also have higher levels of taxation.
} 
Our paper is also related to the growing literature on the elasticity of taxable income, which starts from the observation that taxpayers change their reported income in response to changes in tax rates (Feldstein 1999; Saez et al. 2011). While such behavioral responses were limited to labor supply changes in much of the classical optimal income tax literature (Mirrlees 1971; Sheshinski 1972), it has since been recognized that labor responses are usually small and that additional margins exist which are relatively more sensitive to tax rate changes (Slemrod 1992). Evading taxes is one common way for taxpayers to adjust their taxable income, and our analysis shows that differences in tax evasion behavior, as proxied by tax morale, have implications for the tax policy governments pursue. ${ }^{5}$ When interpreting the tax morale parameter as a proxy for the tax evasion elasticity, our empirical results show that the actual distribution of tax burdens is indeed associated with these elasticities, i.e., governments take this information into account when designing actual tax systems. ${ }^{6}$ Therefore, our analysis also provides an empirical verification of the inverse elasticity rule of optimal taxation, which, to the best of our knowledge, has not been tested empirically for income taxation before.

The remainder of the paper is set up as follows. We develop a simple model of tax policy with tax morale in section 2. Section 3 describes the data sources and presents summary statistics. The empirical strategy and the results are presented in section 4. Section 5 provides several sensitivity analyses. Finally, section 6 concludes.

\section{The Model}

In this section we set up a simple model of optimal taxation with tax morale. Income groups have heterogeneous levels of tax morale and maximize their utility with respect to their labor supply and evasion decisions. Governments may tax different income groups differently. The optimal policy maximizes an objective function which may be interpreted as a welfare function or a function reflecting political influence. The optimal tax rates set by the government then depend, among other things, on the level of tax morale of the different groups. Groups with a high level of tax morale are taxed more heavily because, other things equal, their reported income reacts less elastically to tax rate changes than the reported income of groups with

\footnotetext{
${ }^{5}$ See, e.g., Slemrod and Yitzhaki (2002) for a survey of optimal policy design in the presence of tax evasion; more recently, Chetty (2009) analyzes the welfare implications of accounting for tax evasion and avoidance in the taxable income elasticity.

${ }^{6}$ See, e.g., Saez (2001) for an optimal income tax model based on labor supply elasticities which is extended by Saez et al. (2011) and Piketty et al. (2011) to take tax evasion into account. Cremer and Gahvari (1993) provide a model of commodity taxation including tax evasion.
} 
lower tax morale.

\subsection{Households}

Consider an economy with $n$ groups of households, $i=1, \ldots, n$. For simplicity, we normalize group size to unity, i.e., there is one household representing each group. We model tax morale as follows. We assume that households can easily evade taxes, but doing so gives rise to a subjective cost. The cost function is given by $0.5 e_{i}^{2} m_{i}$, where $e_{i}$ is undeclared income of group $i$ and $m_{i}$ is a positive parameter which captures differences in tax morale - the intrinsic motivation to honestly pay taxesacross groups. Groups with a high value of $m_{i}$ have a high level of tax morale, and vice versa. Of course, this approach to modeling tax morale is very simple, and many other approaches may be contemplated. However, our key result does not depend on this particular approach. In Appendix B, we show that another approach, where taxpayers face 'moral costs' only if $e_{i}$ exceeds some critical threshold, leads to the same result regarding the impact of tax morale on group specific tax rates.

We assume a simple utility function for household $i$ which is given by

$$
u_{i}=c_{i}-\frac{l_{i}^{2}}{2 a_{i}}-0.5 e_{i}^{2} m_{i}
$$

where $c_{i}$ is consumption, $l_{i}$ is labor supply and $a_{i}$ is a parameter reflecting the disutility of work. Following Feldstein (1999), it is convenient to express utility in terms of earned income $y_{i}=l_{i} w_{i}$, where $w_{i}$ is the wage rate of household $i$ and declared income $d_{i}=y_{i}-e_{i}$, which yields

$$
u_{i}=c_{i}-\frac{1}{2 a_{i}}\left(\frac{y_{i}}{w_{i}}\right)^{2}-0.5\left(y_{i}-d_{i}\right)^{2} m_{i}
$$

The household's budget constraint is

$$
c_{i}=y_{i}-t_{i} d_{i}
$$

where $t_{i}$ is the income tax rate. The household chooses earned income $y_{i}$ and declared income $d_{i}$ to maximize utility, subject to the budget constraint. This yields the following optimal choices:

$$
\begin{aligned}
y_{i}^{*} & =a_{i} w_{i}^{2}\left(1-t_{i}\right), \\
d_{i}^{*} & =a_{i} w_{i}^{2}\left(1-t_{i}\right)-\frac{t_{i}}{m_{i}} .
\end{aligned}
$$




\subsection{The Government}

The government finances a given revenue target $R$ using a wage tax, which may differ across household groups. The government budget constraint is given by

$$
R=\sum t_{i} d_{i}
$$

Using (1) and (2), this can be expressed as

$$
R=\sum t_{i}\left(a_{i} w_{i}^{2}\left(1-t_{i}\right)-\frac{t_{i}}{m_{i}}\right)
$$

In the decision making process of the government, each group $i$ is given a weight $b_{i}$, which may be interpreted either as a welfare weight or as a parameter reflecting relative political influence. The government maximizes the objective function

$$
W=\sum b_{i} u_{i}
$$

subject to (3). The optimal tax rate levied on group $i$ is given by the formula

$$
t_{i}^{*}=\frac{\left(\eta-b_{i}\right)}{\left(2 \eta-b_{i}\right)} \frac{a_{i} w_{i}^{2}}{a_{i} w_{i}^{2}+\frac{1}{m_{i}}}
$$

where $\eta$ is the marginal cost of public funds. It thus turns out that the optimal tax imposed on group $i$ is higher, the higher $m_{i}$, i.e. the higher the tax morale of group $i$, and vice versa.

While it is straightforward to generalize our model in various aspects, we opt for the simplest model possible, which includes the features and channels we wish to explore empirically. For instance, we do not distinguish between evasion and avoidance. We also do not build in detection probabilities and penalties. We assume that these are all implicitly captured in the model parameters on evasion and tax morale. Including these features does not change the general implications of our model. ${ }^{7}$ Modeling the presence of tax morale as subjective costs in the utility function has, to the best of our knowledge, not been introduced into the literature on tax morale before. The same problem could also be formulated in terms of a 'warm

\footnotetext{
${ }^{7}$ In principle, it would be possible to construct a richer model, which allows for tax avoidance (e.g., income shifting) in addition to evasion and that would allow for sorting of individuals into tax brackets. As evasion implies a tax rate of zero while avoidance or income shifting yields a positive (but smaller) tax rate, our main results would not change in that case. Simonovits (2011) builds on an earlier version of our paper and extends our model by introducing redistributive concerns, but does not derive different conclusions in his numerical simulations. Traxler (2010) allows tax morale to be endogenous and incorporates it into the seminal tax evasion framework of Allingham and Sandmo (1972).
} 
glow' effect, i.e., the intrinsic satisfaction of doing the right thing when complying with the tax law.

\subsection{Hypothesis}

Our theoretical model yields the following hypothesis:

Hypothesis: Group $i$ 's efficient tax rate $t_{i}$ increases with group $i$ 's tax morale parameter $m_{i}$.

Clearly, this hypothesis is well in line with standard results of optimal income tax theory following Ramsey (1927) or Mirrlees (1971). Groups with a higher responsiveness to taxation should be taxed lower than groups with low levels of responsiveness, i.e., a low elasticity of taxable income (e.g., Feldstein 1999 and Saez et al. 2011).

The next step in the analysis is to operationalize our hypothesis. This requires us to classify individuals into groups as we argue that governments cannot observe individual tax morale (which is private information). Policymakers only observe how certain groups with certain observable characteristics respond to taxation. Furthermore, full discrimination in terms of taxation is neither legally nor economically feasible. As we are interested in the personal income tax, a natural place to start is income. For various reasons, governments levy different tax rates for different levels of income (tax brackets) and hence tax distinct income groups differently. When doing so they take into account that different income groups have different levels of tax morale and adjust their taxation of the groups accordingly. Therefore, we classify individuals by income groups and restate our hypothesis as follows:

Testable Hypothesis: Group $i$ 's mean tax rate $\overline{t_{i}}$ increases with group $i$ 's mean tax morale $\overline{m_{i}}$,

where $\overline{t_{i}}$ and $\overline{m_{i}}$ are $t_{i}$ and $m_{i}$, respectively, mean-averaged across individuals within income group $i$. This hypothesis can be tested with any data set that classifies individuals by income and for which both tax rates and tax morale are available at the income group or individual level.

\section{Data and Operationalization}

While we know of no single data set that jointly satisfies all the data requirements mentioned in section 2.3, it is possible to construct such a data set using information 
from different sources. In order to test our hypothesis empirically, we combine micro data on tax morale and other covariates from the World Values Survey (WVS) and European Values Survey (EVS) (EVS/WVS 2006; WVS 2009) with information on tax rates from the World Tax Indicators (WTI) (Sabirianova-Peter et al. 2010). Below we discuss each data source and define our measures of tax morale and tax rates.

The $W V S / E V S$ is the most common data source in tax morale research. It is a worldwide survey which collects comparative data on many different values and attitudes using standardized questionnaires for representative national samples of at least 1000 respondents per country (Inglehart n.d.). The surveys are conducted by professional scientific institutions and performed through face-to-face interviews at the respondents' home and in their respective national language. ${ }^{8}$ We employ all five waves, which were carried out between 1981-1984, 1989-1993, 1994-1998, 1999-2004, and 2005-2008, respectively.

Our key explanatory variable, tax morale, is measured by individuals' responses to the following question:

Please tell me for the following statement whether you think it can always be justified, never be justified, or something in between: 'Cheating on taxes if you have the chance'.

The question is measured on a ten-scale index with one (1) meaning 'never justifiable' and ten (10) meaning 'always justifiable'. Although this question has been used very frequently in the literature to capture tax morale (e.g., Slemrod 2003, Alm and Torgler 2006, Richardson 2006 and Halla 2010), it is not free of bias. For example, Andreoni et al. (1998) argue that people might overstate their degree of morality in self-reports such as the WVS and those who have evaded might want to excuse their behavior by declaring a high tax morale. Elffers et al. (1987) find that there are significant differences between actual tax evasion and self-reported tax evasion in surveys. Nevertheless, asking about tax morale is less blunt than asking about tax evading behavior, and so the degree of honesty should be higher (Frey and Torgler 2007). Another shortcoming of the question is the fact that taxpayers might find tax evasion justifiable if tax revenue is used for, say, financing a dictator's war machine (Frey and Torgler 2007).

Nonetheless, previous robust evidence shows that low WVS levels of tax morale are associated with high tax evasion and vice versa (Erard and Feinstein 1994; Torgler and Schneider 2009; Halla 2010). This provides evidence in our favor of the

\footnotetext{
${ }^{8}$ Inglehart (2000) provides more comprehensive information on the WVS.
} 
view that true tax evasion behaviour can be proxied with responses to questions about tax morale. Hence, we think that it is appropriate to measure tax morale with this question.

In addition, the WVS/EVS contains information on gross income for 10 income groups (brackets). ${ }^{9}$ Therefore, we know each individual's income group and tax morale. We use this information to define two measures of tax morale for our empirical analysis: i) 'tax morale index' represents income-group averages of the original 10-scale variable as reported in the survey; ii) 'tax morale dummy' is based on a dummy variable that is equal to 1 for individuals who report the highest level of tax morale ( 1 on the original scale) and ' 0 ' for individuals who report a value greater than 1. It follows that 'tax morale dummy' is the share of individuals in each income-group that report the highest possible level of tax morale. ${ }^{10}$ Both variables are coded such that a higher value implies a higher level of tax morale.

Unlike tax morale, which is covered at the individual level across countries and time in the WVS/EVS, tax rates at this level are more difficult to obtain. Of course, statutory variables, such as the top marginal personal income tax rate, have very wide country year coverage and are available from many sources. However, our analysis requires tax rates that vary across time, countries, and income groups. We rely on data from the recently published World Tax Indicator database to overcome these challenges. This large and rather new panel data set covers personal income tax structures at the country level in 189 countries for the period 1981 to 2005 (Sabirianova-Peter et al. 2010). Because it contains the complete national income tax structures, including statutory rates, tax brackets, country-specific tax formulae, standard deductions and tax credits among others, the data allow us to compute average and marginal tax rates. ${ }^{11}$ More importantly, we are able to calculate these tax rates for any level of gross income and hence at the income group levels reported in the WVS/EVS. ${ }^{12}$ We use the raw WTI data to estimate average (AR) and marginal (MR) tax rates for each income group reported in the WVS/EVS for

\footnotetext{
${ }^{9}$ The provided income steps are adjusted to the respective national income distributions, but they do not reflect income deciles.

${ }^{10}$ This operationalization is commonly used (see, e.g., Alm and Torgler 2006 and Doerrenberg and Peichl 2011).

${ }^{11}$ The WTI collects tax schedule information for single tax payers only. This is not likely to have any noticeable effect on the results since very few countries tax family income (exceptions include Germany, France and the U.S.) or have tax schedules that depend on marital status (SabirianovaPeter et al. 2010).

${ }^{12} \mathrm{~A}$ problem with the survey information is that we do not know whether individuals gave the income reported to tax authorities or their true income. However, we are on the safe side since the potential bias of tax evaders reporting their true income (low morale, high income, high tax rate) leads to an underestimation of the effect of tax morale on tax rates.
} 
each country-year. ${ }^{13}$ Both tax rates adjust for standard deductions and credits and are calculated using country specific tax formulae. ${ }^{14}$ Because there is no adjustment for tax evasion or avoidance, these tax rates are close to, but are not, effective tax rates. Nonetheless, they are superior to using statutory rates.

In order to relate the calculated income group tax rates to the WVS/EVS data, all information from the WVS/EVS are aggregated (means) on the level of country-year income groups. We restrict the sample to employed individuals before aggregating the data, in an effort to limit our analysis to individuals who potentially paid income taxes. We also exclude the respective lowest income group in each country-year observation from our estimations as individuals in theses groups usually do not pay income taxes; hence, we do not observe any variation in taxes within and across these groups. Finally, the aggregated WVS/EVS information are merged with the tax rates from the WTI. It seems reasonable to aggregate individual information -including tax morale - on the income group level because i) it is very unlikely that policy makers have individual level information on tax morale and ii) even if they do, they could not tax each person individually. In addition, grouping can alleviate measurement error in the covariates. Table 5 in the Appendix provides summary statistics for the relevant variables.

\section{Empirical Strategy and Results}

This section describes our empirical strategy and results. In our regressions, we employ marginal (MR) and average (AR) tax rates as dependent variables and focus on two main explanatory variables: 'tax morale index' and 'tax morale dummy'. ${ }^{15}$ All estimations display panel-adjusted standard errors that account for clustering effects of a certain country's income groups and are robust to the presence of heteroscedasticity. The panel is highly unbalanced and many income groups are only represented once, which makes it difficult to employ country fixed-effects. ${ }^{16}$

\footnotetext{
${ }^{13}$ Estimation is restricted to 52 countries that recorded gross income. For a sensitivity check (see section 5), we also estimate lead tax rates to analyze the impact of tax morale in year $t$ on tax rates in $t+1$.

${ }^{14} \mathrm{We}$ are not able to adjust for deductions and credits that vary by individual characteristics (e.g., child credits). See Sabirianova-Peter et al. (2010) for a more detail description of the WTI and the tax rates.

${ }^{15}$ Recall that 'tax morale dummy' is the share of individuals in each income group that reports the highest level of tax morale whereas 'tax morale index' is the average of the 10-point scale value.

${ }^{16}$ We show, however, that our hypothesis holds up to the inclusion of country-group fixed-effects, as well as actual country fixed-effects in estimations on the individual (person) level. See section 5.1 for more details.
} 


\subsection{Empirical Model}

OLS regressions, which are reported in Table 7 in the Appendix, provide evidence of a positive association (conditional correlation) between group-level tax morale and tax rates. This is consistent with our theoretical predictions. However, we believe the OLS estimates are biased for reasons put forward below. Ex-ante, the direction of the bias is not clear because the relationship between tax rates and tax morale is found to be ambiguous in the literature (Torgler and Schneider 2007).

The first issue we have to address is reverse causality. While we aim to estimate the effect of tax morale on tax rates, previous research has established a feedback effect from tax rates (or the general system of taxation) to the level of tax morale (see, e.g., Doerrenberg and Peichl 2011). Additionally, we are not able to control for the actual extent of tax evasion or the size of the shadow economy. Since both variables are known determinants of tax rates and tax morale, we must also contend with omitted variable bias. Both issues imply OLS estimates are biased and that a different identification strategy is required if we are to make any causal inference. Therefore, we employ an instrumental variable, $z_{i j t}$, and estimate the model by twostage least squares (2SLS). An instrument that is sufficiently strongly correlated with tax morale, but not with the error term in the structural equation of interest, will provide us with exogenous variation, which can be exploited to overcome the endogeneity problem and to identify the effect of interest. The first-stage regression in our instrumental variable estimations reads

$$
\overline{m_{i j t}}=\gamma+\eta z_{i j t}+\bar{X} \delta+C \phi+v_{i}+\theta_{t}+\epsilon_{i j t}
$$

where subscripts $i, j$, and $t$ indicate income group, country, and survey wave respectively; $z_{i j t}$ is one or both of our instruments (see section 4.2); $\bar{m}_{i j t}$ is one of our tax morale measures ('tax morale index' or 'tax morale dummy'); and $v_{i}, \theta_{t}$, and $\epsilon_{i j t}$ are income group dummies, survey wave dummies, and iid error terms, respectively.

Finally, $\bar{X}$ is a vector of income group control variables and $C$ is a vector of country-level control variables. $\bar{X}$ contains several confounding variables on the income-group level: marital status, number of children, religiosity, and employment status. ${ }^{17}$ All variables in $\bar{X}$ are obtained from the WVS/EVS and averaged over

17 These are known determinants of tax morale and tax rates (e.g. Torgler 2007). Note that the theoretical relationship between income and tax morale is not clear (see Doerrenberg and Peichl 2011). On the one hand, evasion yields higher returns for high-income earners - especially in countries with progressive tax systems. On the other, people earning high incomes might have higher societal stakes and therefore be more affected by sanctions, i.e., losing a well-paid job. Accordingly, the empirical picture is ambiguous as well. Whereas Konrad and Qari (2009) cannot find any significant effects using European data, a negative relationship is found by Torgler (2006) for a larger set of countries. 
income groups. We include GDP per capita (in PPP), GDP growth rate, and foreign direct investments (FDI) in vector $C$ in order to account for confounding countrylevel variables. All country-level variables are taken from the Worldbank's World Development Indicators (World Bank 2010). Our specification hence exploits acrosscountry and within-country variation in tax morale to explain heterogenous levels of tax rates.

Intuitively, the IV estimations will use the fitted values from the first-stage equation (5) as substitutes for $\overline{m_{i j t}}$ in the following OLS regression of tax rates on income group's characteristics:

$$
\overline{t_{i j t}}=\alpha+\beta \overline{m_{i j t}}+\bar{X} \delta+C \phi+v_{i}+\theta_{t}+\epsilon_{i j t},
$$

where $\overline{m_{i j t}}$ is one of our tax morale measures but instrumented by $z_{i j t}$, and $\overline{t_{i j t}}$ is one of our tax rate measures (AR or MR). Hence, the identification of the impact of tax morale on tax rates will rely only on that part of the variation in $m_{i j t}$, which is driven by exogenous variables.

\subsection{Instruments}

Finding suitable instruments is generally a difficult task. We require an instrument that is related to income group tax morale, but does not have any link to the same income group's tax rate. Given the structure of our dataset, we also require the instrument to have sufficient variation across income groups. We mainly employ two instruments in our IV estimations, which we base on other questions asked in the WVS/EVS: ${ }^{18}$

Dodging fares justifiable? For our first instrument we exploit the answer to the question: 'Tell me whether you think it can always be justified, never be justified or something in between, to avoid a fare on public transportation'. Respondents are asked to respond to the question on a 10 point scale. The instrument and tax morale are fairly correlated and we do not suffer from a weak instrument (see below). Of course, many individuals who report high tax morale also develop a high level of 'dodging-fares-morale' and hence we are able to observe a positive relationship between the two variables.

As for exclusion restriction, we assume that the share of people in each income group who have a high 'dodging-fares-morale' is not related to their tax rate. A pos-

\footnotetext{
${ }^{18}$ Lubian and Zarri (2011) also use tax morale as an explanatory variable (to explain happiness) and instrument it with another question from the same survey. They, however, use a different dataset (for Italy) and their instrument is not available in our data.
} 
sible drawback occurs for countries where public transportation is operated by the government and where taxes and public transportation are financed from the same budget: if, in those countries, many people dodge fares, the transportation sector might have to be cross-subsidized by tax money; implying that, ceteris paribus, taxes might be higher in such countries. However, in most countries public transportation is privately or semi-privately run. In the latter case, usually the transportation companies are on a different budget than the tax legislating government.

Child unselfishness Our second instrument is based on a question concerning attitudes on educating and raising one's own children: 'Here is a list of qualities that children can be encouraged to learn at home. Which, if any, do you consider to be especially important?' As an instrument, we use the share of people in each income group who replied that 'unselfishness' is one of the key qualities children should be encouraged to learn. As we would expect intuitively, this variable is also fairly positively correlated with tax morale. Paying taxes can be seen as a service to society: taxes finance public goods and social benefits. Individuals who have low tax morale and tend to evade their taxes are less likely to believe that it is especially important for their children to develop an unselfishness character.

We also assume the exclusion restriction holds: The share of people who believe that unselfishness is important should not affect the level of taxes. What is more, we do not expect reverse causality problems either. The answer to this question is not affected by the tax system or tax rates. The question for unselfishness of children is located in a different module (A) of the survey than the questions for the justifiability of tax evasion and dodging fares (module F). This leads us to believe the replies to both questions were given independently of each other.

Validity of instruments and 1st-stage results Instruments need to satisfy two conditions: they must be correlated with the endogenous variable and orthogonal to the error term. We have to rely on economic theory and intuitive reasoning to back the latter (see the discussion above). The former can, however, be tested by looking at the first-stage results of regressions of the instrumented variable - tax morale - on all exogenous variables and the instruments. Tables 8 and 9 in the appendix display first-stage results of our baseline specifications. As expected, both instruments - 'dodging fares justifiable?' and 'child unselfishness' - have a significant positive impact on tax morale after conditioning on all confounding variables. The first-stage results hence confirm our intuition given above.

The F-statistics of excluded instruments - reported in Tables 1 and 2-are well 
larger than 10 when 'cheating on public transportation' is used as the instrument. ${ }^{19}$ The respective F-statistics for specifications with 'child unselfishness' alone are lower: estimations employing 'tax morale index' as the instrumented variable display Fstatistics of around 7, whereas they are slightly larger than 10 (around 13) when 'tax morale dummy' is the endogenous variable. ${ }^{20}$ Our over-identified estimations, where we use both available instruments, disclose F-statistics of excluded instruments of above 40; thus putting us in the 'safe zone'. Finally, for our overidentified estimations we mostly cannot reject the null hypotheses of the Hansen test of overidentification at reasonable levels of significance. An exception is the estimation with AR serving as the dependent variable and tax morale index being the explanatory variable where we can only reject the null hypothesis at the $6 \%$ level (the corresponding p-values are reported in the result tables below).

\subsection{Baseline Results}

Baseline results using 2SLS are presented in Tables 1 and 2 for AR and MR, respectively. The results confirm our hypothesis. For both operationalizations of our main explanatory variable - tax morale on the 10-point scale and 'tax morale dummy' based on a dummy with 1 standing for the highest level of tax morale - we observe that a higher level of tax morale is associated with, ceteris paribus, higher taxation. Increasing 'tax morale index' by one standard deviation in the 'cheating' specification increases the tax rate by 0.6 standard deviations. The estimate is significantly different from zero at the $1 \%$ level. The point estimates are higher, but less significant when 'child unselfishness' is employed to instrument tax morale: a one standard deviation increase in 'tax morale index' increases the tax rate by 1.09 standard deviations. In the overidentified case, where we use both available instruments, the coefficient is highly significant and very close to the point estimate in the 'cheat' specification.

\footnotetext{
${ }^{19} \mathrm{IV}$ estimations are prone to be biased and inconsistent if the correlation between instrument and instrumented variable is too weak and if there are many over-identifying restrictions (Bound et al. 1995). Staiger and Stock (1997) suggest that F-statistics of excluded instruments need to be larger than 10 to exclude a problem of weak instruments.

${ }^{20}$ The former figure might indicate a weak instrument problem. However, Angrist and Pischke (2009a, page 215) note that this is not a mechanical rule and F-statistics smaller than 10 might not always be fatal. In the just-identified case - say, one endogenous variable and one instrument - the two-stage-least-squares (2SLS) estimates are approximately unbiased (median-unbiased) and weak instrument problems only cause second-stage standard errors to be large (Angrist and Pischke 2009a; Angrist and Pischke 2009b, page 209). Even in those specifications with the smallest Fstatistics, we obtain decently small standard errors suggesting that we do not suffer from a weak instrument problem.
} 
Table 1: Effect of Tax Morale on Average Tax Rates

\begin{tabular}{|c|c|c|c|c|c|c|}
\hline & Cheat & Unself & Both & Cheat & Unself & Both \\
\hline \multirow[t]{2}{*}{ Tax morale index } & $10.557^{* * *}$ & $19.185^{* *}$ & $11.486^{* * *}$ & & & \\
\hline & $(2.397)$ & $(9.239)$ & $(2.399)$ & & & \\
\hline \multirow[t]{2}{*}{ Tax morale dummy } & & & & $52.257^{* * *}$ & $61.357^{* * *}$ & $56.071^{* * *}$ \\
\hline & & & & $(11.640)$ & $(22.768)$ & $(10.909)$ \\
\hline \multirow[t]{2}{*}{ Income group 3} & 0.272 & -0.118 & -0.067 & 1.381 & 1.387 & 1.074 \\
\hline & $(3.616)$ & $(4.200)$ & $(3.730)$ & $(3.525)$ & $(3.449)$ & $(3.627)$ \\
\hline \multirow[t]{2}{*}{ Income group 4} & 0.434 & -0.279 & -0.093 & 1.826 & 2.069 & 1.359 \\
\hline & $(3.707)$ & $(4.510)$ & $(3.855)$ & $(3.577)$ & $(3.473)$ & $(3.702)$ \\
\hline \multirow[t]{2}{*}{ Income group 5} & 2.198 & 1.289 & 1.581 & 2.723 & 2.358 & 2.078 \\
\hline & $(3.872)$ & $(4.461)$ & $(4.024)$ & $(3.833)$ & $(3.731)$ & $(3.976)$ \\
\hline \multirow[t]{2}{*}{ Income group 6} & 4.773 & 4.276 & 4.200 & 5.454 & 5.086 & 4.846 \\
\hline & $(3.914)$ & $(4.517)$ & $(4.076)$ & $(3.836)$ & $(3.766)$ & $(3.984)$ \\
\hline \multirow[t]{2}{*}{ Income group 7} & $7.504^{*}$ & $7.571^{*}$ & $6.754^{*}$ & $8.702^{* *}$ & $8.530^{* *}$ & $8.002^{* *}$ \\
\hline & $(3.871)$ & $(4.540)$ & $(4.072)$ & $(3.787)$ & $(3.764)$ & $(3.970)$ \\
\hline \multirow[t]{2}{*}{ Income group 8} & $10.208^{* * *}$ & $10.385^{* *}$ & $9.596^{* *}$ & $11.171^{* * *}$ & $10.648^{* * *}$ & $10.505^{* * *}$ \\
\hline & $(3.662)$ & $(4.397)$ & $(3.851)$ & $(3.574)$ & $(3.657)$ & $(3.747)$ \\
\hline \multirow[t]{2}{*}{ Income group 9} & $12.548^{* * *}$ & $12.804^{* * *}$ & $12.021^{* * *}$ & $13.094^{* * *}$ & $12.530^{* * *}$ & $12.769^{* * *}$ \\
\hline & $(3.877)$ & $(4.799)$ & $(4.077)$ & $(3.790)$ & $(3.896)$ & $(3.971)$ \\
\hline \multirow[t]{2}{*}{ Income group 10} & $16.236^{* * *}$ & $18.217^{* * *}$ & $16.132^{* * *}$ & $16.140^{* * *}$ & $15.767^{* * *}$ & $15.890^{* * *}$ \\
\hline & $(3.800)$ & $(5.804)$ & $(3.964)$ & $(3.591)$ & $(4.022)$ & $(3.741)$ \\
\hline \multirow[t]{2}{*}{ GDP per capita } & $0.419^{* * *}$ & $0.361^{* * *}$ & $0.414^{* * *}$ & $0.531^{* * *}$ & $0.469^{* * *}$ & $0.537^{* * *}$ \\
\hline & $(0.125)$ & $(0.124)$ & $(0.131)$ & $(0.128)$ & $(0.111)$ & $(0.132)$ \\
\hline \multirow[t]{2}{*}{ GDP growth } & -0.134 & -0.390 & -0.163 & -0.052 & -0.178 & -0.086 \\
\hline & $(0.231)$ & $(0.286)$ & $(0.239)$ & $(0.230)$ & $(0.218)$ & $(0.240)$ \\
\hline \multirow[t]{2}{*}{ FDI, net inflows } & $-0.033^{* * *}$ & -0.012 & $-0.032^{* * *}$ & $-0.042^{* * *}$ & $-0.034^{* * *}$ & $-0.041^{* * *}$ \\
\hline & $(0.009)$ & $(0.019)$ & $(0.009)$ & $(0.008)$ & $(0.008)$ & $(0.008)$ \\
\hline \multirow[t]{2}{*}{ constant } & $-57.419^{* * *}$ & $-119.234^{*}$ & $-64.283^{* * *}$ & -6.245 & -8.819 & -7.752 \\
\hline & $(20.087)$ & $(66.986)$ & $(20.093)$ & $(11.084)$ & $(13.900)$ & $(11.029)$ \\
\hline $\mathrm{N}$ & 504 & 567 & 495 & 504 & 567 & 495 \\
\hline F-stat excl. instr & 91.47 & 6.96 & 49.88 & 74.53 & 13.65 & 43.26 \\
\hline p-val Hansen overid & l & l & 0.06 & 1 & 1 & 0.14 \\
\hline
\end{tabular}

[1] Dep. Variable: AR [2] 2SLS estimations [3] Instruments: 'Dodging fares justifiable', 'Child unselfishness' or both [4] Cluster-adjusted standard errors [5] Sociodemographic controls and wave dummies included but not displayed [6] Income group 2 is reference category [7] $*<0.10, * *<0.05, * * *<0.01$ [8] First-stage results shown in Table 8 in the appendix

Of course, the absolute coefficients on 'tax morale dummy' are much larger than on 'tax morale index'. With this dummy being the independent and instrumented variable, the coefficient stands for a change from the lowest to the highest level of tax morale. A one standard deviation increase in 'tax morale dummy' in- 
creases the tax rate by 0.61 in the 'cheat' specification and 0.72 standard deviations in the 'unselfishness' specification. The point estimate in the overidentified model lies between the coefficients in the just-identified models and is significantly different from zero at the $1 \%$ level. Again, the coefficient stemming from the overidentidfied estimation is very close to the corresponding one in the 'cheat' specification. It is clear, then, that the results are in accordance with the 'tax morale index' specifications.

Table 2 presents the results with the marginal tax rate (MR) as the dependent variable. The results and patterns are very similar to those described above. An increase in 'tax morale index' ('tax morale dummy') by one standard deviation increases MR by 0.51 (0.53) standard deviations with 'cheat' as the IV and by 0.62 (0.42) in the 'unselfishness' specification. The low conditional correlation between 'unselfishness' and 'tax morale' causes the coefficient in specification 2 not to be significant on the $10 \%$ level; the corresponding p-value is 0.12 and therefore very close to being significant. The overidentified estimation yields highly significant estimates that are very close to the corresponding values in the just-identified cases. In the latter three specifications, where 'tax morale dummy' serves as the explanatory variable, all three coefficients of interest are positive and significant. While the coefficient in the 'unself' specification was slightly insignificant with 'tax morale index' as the explanatory variable, the respective coefficient is now significant at the $10 \%$ level.

Table 2: Effect of Tax Morale on Marginal Tax Rates

\begin{tabular}{lcccccc}
\hline \hline & cheat & unself & both & cheat & unself & both \\
\hline Tax morale index & $8.974^{* * *}$ & 10.847 & $9.544^{* * *}$ & & & \\
Tax morale dummy & $(2.206)$ & $(7.053)$ & $(2.209)$ & & & \\
& & & $44.686^{* * *}$ & $35.380^{*}$ & $46.234^{* * *}$ \\
Income group 3 & & & $(10.809)$ & $(20.450)$ & $(10.215)$ \\
& 4.884 & 5.323 & 4.651 & 5.722 & $6.069^{*}$ & 5.492 \\
Income group 4 & $(3.566)$ & $(3.524)$ & $(3.659)$ & $(3.480)$ & $(3.206)$ & $(3.555)$ \\
& 5.711 & $6.167^{*}$ & 5.286 & $6.786^{*}$ & $7.384^{* *}$ & $6.384^{*}$ \\
Income group 5 & $(3.698)$ & $(3.715)$ & $(3.820)$ & $(3.595)$ & $(3.269)$ & $(3.691)$ \\
& $9.072^{* *}$ & $8.977^{* *}$ & $8.492^{* *}$ & $9.420^{* *}$ & $9.477^{* * *}$ & $8.809^{* *}$ \\
Income group 6 & $(3.793)$ & $(3.755)$ & $(3.921)$ & $(3.745)$ & $(3.445)$ & $(3.854)$ \\
& $13.221^{* * *}$ & $13.189^{* * *}$ & $12.683^{* * *}$ & $13.705^{* * *}$ & $13.550^{* * *}$ & $13.120^{* * *}$ \\
Income group 7 & $(3.655)$ & $(3.536)$ & $(3.791)$ & $(3.582)$ & $(3.224)$ & $(3.695)$ \\
& $16.040^{* * *}$ & $16.144^{* * *}$ & $15.375^{* * *}$ & $16.975^{* * *}$ & $16.615^{* * *}$ & $16.308^{* * *}$ \\
Income group 8 & $(3.610)$ & $(3.525)$ & $(3.776)$ & $(3.522)$ & $(3.229)$ & $(3.662)$ \\
& $18.719^{* * *}$ & $18.492^{* * *}$ & $18.177^{* * *}$ & $19.465^{* * *}$ & $18.580^{* * *}$ & $18.835^{* * *}$ \\
Income group 9 & $(3.507)$ & $(3.496)$ & $(3.659)$ & $(3.428)$ & $(3.241)$ & $(3.560)$ \\
& $20.703^{* * *}$ & $20.343^{* * *}$ & $20.184^{* * *}$ & $21.099^{* * *}$ & $20.130^{* * *}$ & $20.708^{* * *}$ \\
& & & & & continues on next page
\end{tabular}




\begin{tabular}{lcccccc} 
& & & \multicolumn{3}{c}{ continued from previous page } \\
& $(3.579)$ & $(3.667)$ & $(3.733)$ & $(3.505)$ & $(3.314)$ & $(3.632)$ \\
Income group 10 & $23.677^{* * *}$ & $23.915^{* * *}$ & $23.547^{* * *}$ & $23.531^{* * *}$ & $22.492^{* * *}$ & $23.244^{* * *}$ \\
& $(3.633)$ & $(4.370)$ & $(3.762)$ & $(3.482)$ & $(3.475)$ & $(3.590)$ \\
GDP per capita & $0.416^{* * *}$ & $0.409^{* * *}$ & $0.409^{* * *}$ & $0.512^{* * *}$ & $0.471^{* * *}$ & $0.511^{* * *}$ \\
& $(0.114)$ & $(0.091)$ & $(0.118)$ & $(0.117)$ & $(0.090)$ & $(0.119)$ \\
GDP growth & 0.146 & -0.042 & 0.142 & 0.216 & 0.077 & 0.211 \\
& $(0.214)$ & $(0.209)$ & $(0.218)$ & $(0.210)$ & $(0.176)$ & $(0.215)$ \\
FDI, net inflows & $-0.025^{* * *}$ & -0.018 & $-0.024^{* * *}$ & $-0.032^{* * *}$ & $-0.030^{* * *}$ & $-0.032^{* * *}$ \\
& $(0.009)$ & $(0.014)$ & $(0.009)$ & $(0.008)$ & $(0.007)$ & $(0.008)$ \\
constant & $-49.433^{* * *}$ & -62.842 & $-53.785^{* * *}$ & -5.867 & -0.554 & -6.421 \\
& $(17.510)$ & $(50.952)$ & $(17.425)$ & $(9.605)$ & $(11.517)$ & $(9.458)$ \\
\hline N & 503 & 566 & 494 & 503 & 566 & 494 \\
F-stat excl. instr & 91.37 & 7.05 & 49.95 & 73.03 & 13.32 & 42.23 \\
p-val Hansen overid & $/$ & $/$ & 0.32 & $/$ & $/$ & 0.57 \\
\hline \hline
\end{tabular}

[1] Dep. Variable: MR [2] 2SLS estimations [3] Instruments: 'Dodging fares justifiable', 'Child unselfishness' or both [4] Cluster-adjusted standard errors [5] Sociodemographic controls and wave dummies included but not displayed [6] Income group 2 is reference category [7] $*<0.10, * *<0.05, * * *<0.01$ [8] First-stage results shown in Table 9 in the appendix

Regarding the effect of confounding variables, we mostly observe theoretically expected effects: We include dummies for each income group in the analysis in order to capture non-linear effects of income. Reflecting the progressivity of tax systems in almost all countries in the analysis, we clearly observe that higher income groups pay higher tax rates. Dummy variables for each survey wave (not displayed in the result table) indicate that there is a trend in time towards lower levels of taxation - a trend that is widely recognized (Sabirianova-Peter et al. 2010). We further observe that tax rates are higher in rich countries and, all else equal, a higher level of Foreign Direct Investments (FDI, as a proxy for openness) yields lower rates. We also see from the data that groups with high average numbers of children face lower rates (for reasons of clear arrangement, the displayed result tables do not show the coefficients of included sociodemographic control variables).

Discussion Overall, we find international cross-country evidence that is consistent with our hypothesis in all specifications. We find effects that are quite robust to both the use of different IVs and the operationalization of the explanatory variable 'tax morale'. It seems to be the case that income groups with high levels of tax morale, ceteris paribus, face systematically higher average and marginal tax rates.

Imbens and Angrist (1994) note that the coefficients in IV estimations should be interpreted as 'Local Average Treatment Effects' (LATE). That is, the observed 
effect is the effect of the so-called complier population (see also Angrist et al. 1996). In our case, this implies that the reported coefficients are restricted to the subsample of individuals that would change their level of tax morale in response to a hypothetical change in the instruments. The IV approach prevents the hazard of reverse causality as we assume the instruments to be unrelated to the dependent variables. However, depending on which instrument is used, we observe different magnitudes in coefficients. This should be a sign of caution indicating that we cannot take the actual magnitude of the coefficients for granted. The robust positive sign, nevertheless, provides evidence backing our hypothesis. Even in those specifications with low F-statistics of excluded instruments, and hence higher standard errors, we do not expect the results to be biased as they are just-identified.

\section{Sensitivity Checks}

We conduct two broad categories of robustness checks in order to increase confidence in our results. First, we examine the source of variation used to identify the effect of tax morale by estimating models with regional fixed effects and country fixed effects. These extensions are particularly important since the theoretical model focuses on within country variation. The second category addresses other important, but relatively minor issues that might affect our results. We describe each of these categories - in turn, starting with fixed effect models.

\subsection{Fixed Effects Models}

It is possible that our results are driven by genuine differences between countries, rather than within country variation, which we are also exploiting. For example, results may be biased if high-tax countries also happen to have high average levels of tax morale and the instrumental variables. To check this, we employ fixed-effects regressions. ${ }^{21}$ Running country-fixed-effect estimations in our case, however, causes problems of multicollinearity and too few degrees of freedom because the sample is highly unbalanced; many countries participated in only one wave of the WVS/EVS. We address this problem in two ways. First, following the WVS/EVS literature (e.g. Helliwell 2003), we form groups of countries to reduce the number of country fixedeffect variables. We then estimate a country-group fixed-effects model with eight country groups: English-speaking countries (Anglo-Saxon plus Australia and New Zealand); Continental Europe plus Israel; Scandinavia; Eastern Central Europe;

\footnotetext{
${ }^{21}$ Note, however, that we indirectly account for some country-specific effects in our previous estimations by including country-level control variables in all of our regressions.
} 
former Soviet countries; Latin America; Asia; and (other) Developing Countries (see Table 6 for an overview of country-groups). As shown in Panel A of Table 3 , the country-group fixed-effect estimations yield coefficients that are very close (and also significant) to the baseline specification when 'cheat' is employed as the instrument. ${ }^{22}$

The second attempt to address country-level fixed-effects, involves estimating our models at the individual level. This approach provides greater within country variation than our previous estimations, where we use averages of individual values within income groups. The challenge in implementing this approach is that we do not have individual level data on income. Instead, the WVS provides data on each respondent's income group. Therefore, in order to run individual level estimations, we impute income levels for each respondent in the survey. We employ the following multiple imputation procedure, which is comparable to the approach proposed by Jenkins et al. (2011):

1. For each country year, divide each of the 10 income gropus of the WVS data into 100 equally wide segments. ${ }^{23}$

2. For each of the resulting 100 incomes in each income group, calculate the corresponding (average and marginal) tax rates using the WTI data.

3. Randomly assign one of the 100 incomes (within an income group) to each individual in that income group. This step also automatically assigns tax rates to individuals. Since some groups have more than 100 individuals, it is possible for two or more individuals within a given group to have the same income.

4. Run individual level IV-regressions.

5. Repeat steps 3) and 4) 1000 times.

The average (mean) coefficients of these 1000 replications is used to derive our coefficient of interest. We employ the combination method proposed by Reiter

\footnotetext{
${ }^{22}$ See Tables 4 and 10 for additional specifications with country-group fixed-effects. Because 'unselfishness' is a weak instrument with very small F-statistics of excluded instruments in these fixed-effect estimations, the second-stage results become insignificant. Simple OLS regressions containing country-group fixed effects yield very similar - and even more significant - coefficients than the baseline OLS estimations presented in the Appendix. Additionally, OLS and IV estimations with and without country fixed-effects, on the sample of countries that are part of at least two survey waves, also yield positive point estimates. However, these estimates are not statistically significant due to the smaller sample size.

${ }^{23}$ In principle, it is possible to randomly assign each individual a random income between the lower and upper bounds for the respective income brackets. However, we would not gain more variation in tax rates, whereas the computational procedure would be slightly more difficult.
} 
(2003), and applied by Jenkins et al. (2011), to calculate standard-errors and levels of significance, taking into account the finite number of imputations.

Step 4 includes the following control variables; i) the same individual-level controls as in the baseline, ii) survey wave fixed-effects, iii) income group fixedeffects, and iv) country fixed-effects. We exclude country-level variables from our estimations in order to use the full sample of countries, including those that are only part of one WVS wave. Due to the insignificant results of the 'child' instrument in the country-group fixed-effects estimation (see Section 5.2), and for brevity, we focus on the 'cheat' instrument here. Results from this multiple-imputation regression approach are presented in Panels B and C of Table $3 .^{24}$

Table 3: Fixed-Effect Estimations

\begin{tabular}{lccccc}
\hline Expl. Variable & \multicolumn{2}{c}{ Tax Morale Index } & & \multicolumn{2}{c}{ Tax Morale Dummy } \\
\cline { 2 - 3 } \cline { 5 - 6 } Dependent Variable & $\mathrm{AR}$ & $\mathrm{MR}$ & & $\mathrm{AR}$ & $\mathrm{MR}$ \\
\hline Panel A: Income-group level with Country-Group Fixed-Effects & \\
\hline Tax Morale & $10.506^{* * *}$ & $8.889^{* * *}$ & & $67.365^{* * *}$ & $57.547^{* * *}$ \\
& $(2.494)$ & $(2.348)$ & & $(17.077)$ & $(16.080)$ \\
Observations & 504 & 503 & & 504 & 503 \\
\hline Panel B: Multiple Imputation Approach without Country Fixed-Effects \\
\hline Tax Morale & $1.0584^{* * *}$ & $0.8130^{* * *}$ & & $5.8698^{* * *}$ & $4.5089^{* * *}$ \\
& $(0.2579)$ & $(0.2615)$ & & $(1.4077)$ & $(1.4333)$
\end{tabular}

Panel C: Multiple Imputation Approach with Country Fixed-Effects

\begin{tabular}{lcccc}
\hline Tax Morale & $\begin{array}{c}0.1736^{* * *} \\
0.1562^{* * *}\end{array}$ & $0.9681^{* * *}$ & $0.8710^{* * *}$ \\
$(0.0516)$ & $(0.0503)$ & $(0.2847)$ & $(0.2788)$
\end{tabular}

Observations

$33,022 \quad 33,022$

33,022

33,022

[1] 2SLS IV regressions [2] Instrument: Cheating on Public Transportation

[3] Panel A: Income-group level estimations include same control variables as the baseline specifications [4] Panels B and C: Individual level estimations based on multiple imputation approach. 'Observations' is number of observations per random draw. Control variables as in baseline, but w/o country-level variables. Standard errors in parentheses are calculated following Reiter (2003) [5] $*<0.10, * *<0.05, * * *<0.01$

The multiple imputation approach yields coefficients that are an order of mag-

\footnotetext{
${ }^{24}$ The results from this multiple-imputation regression approach are similar to those obtained from an interval regression, in which we use the lower and upper bounds of the tax rate brackets on the individual level as dependent variables.
} 
nitude smaller than the income group estimates reported in Tables 1 and 2. This can be explained by the increased variation in the explanatory variables (as well as the dependent variable). ${ }^{25}$ Nonetheless, the coefficients - for both 'tax morale index' and 'tax morale dummy' - are positive and statistically different from zero. More importantly, this result holds when we include country fixed-effects. Since all country specific effects are captured and controlled for in Panel $\mathrm{C}$, the positive coefficients can be attributed solely to within-country variation in tax morale. This provides further evidence that our results are not being driven by between country variation. The importance of between country variation can be seen by comparing the coefficients in Panels B and C.

\subsection{Other Robustness Checks}

In our second set of robustness checks, we go back to income-group level estimations and first include a country level measure of bureaucratic quality (ICRG 2011) - a variable found to be a possible determinant of tax morale (Barone and Mocetti 2011) - in order to control for the possibility that countries with less efficient governments have higher tax rates (Brennan and Buchanan 1980). ${ }^{26}$ We also run regressions in which we weight the income groups by the number of their members. Additionally, we restrict the analysis to OECD countries in order to gain insights for a more homogeneous set of countries. Finally, we employ lead tax rates where tax rates in year $t+1$ are related to tax morale in year $t$. Tables 4 (dependent variable: $\mathrm{AR}$ ) and 10 (dependent variable: MR; table displayed in the Appendix) summarize these sensitivity checks.

Table 4: Sensitivity Checks for Average Tax Rate

\begin{tabular}{lccccccc}
\hline \multirow{2}{*}{$\begin{array}{l}\text { Independent Variable } \\
\text { Instrument }\end{array}$} & \multicolumn{3}{c}{ Tax Morale Index } & & \multicolumn{3}{c}{ Tax Morale Dummy } \\
\cline { 2 - 3 } & Cheat & Unself & Both & & Cheat & Unself & Both \\
\hline Tax Morale & $10.557^{* * *}$ & $19.185^{* *}$ & $11.486^{* * *}$ & & $52.257^{* * *}$ & $61.357^{* * *}$ & $56.071^{* * *}$ \\
& & & & & & & continues on next page
\end{tabular}

\footnotetext{
${ }^{25}$ For intuition, consider a simple univariate OLS regression of $y$ on $x$ where the slope coefficient is given by the covariance of $x$ and $y$ over the variance of $x$. Estimation at the individual level allows us to use the maximum available variation in each variable. Because the variation on the individual level is greater than on the group level, the slope coefficient decreases c.p. (the actual change also depends on the change in the covariance). In addition, the smaller coefficients could be an indicator of attenuation bias due to measurement error in the explanatory variables, which may be alleviated by grouping the covariates. Therefore, we prefer to keep the income group level regressions as our baseline specifications.

${ }^{26}$ This variable is not available for all country-year observations which is why we only include it in a robustness check.
} 


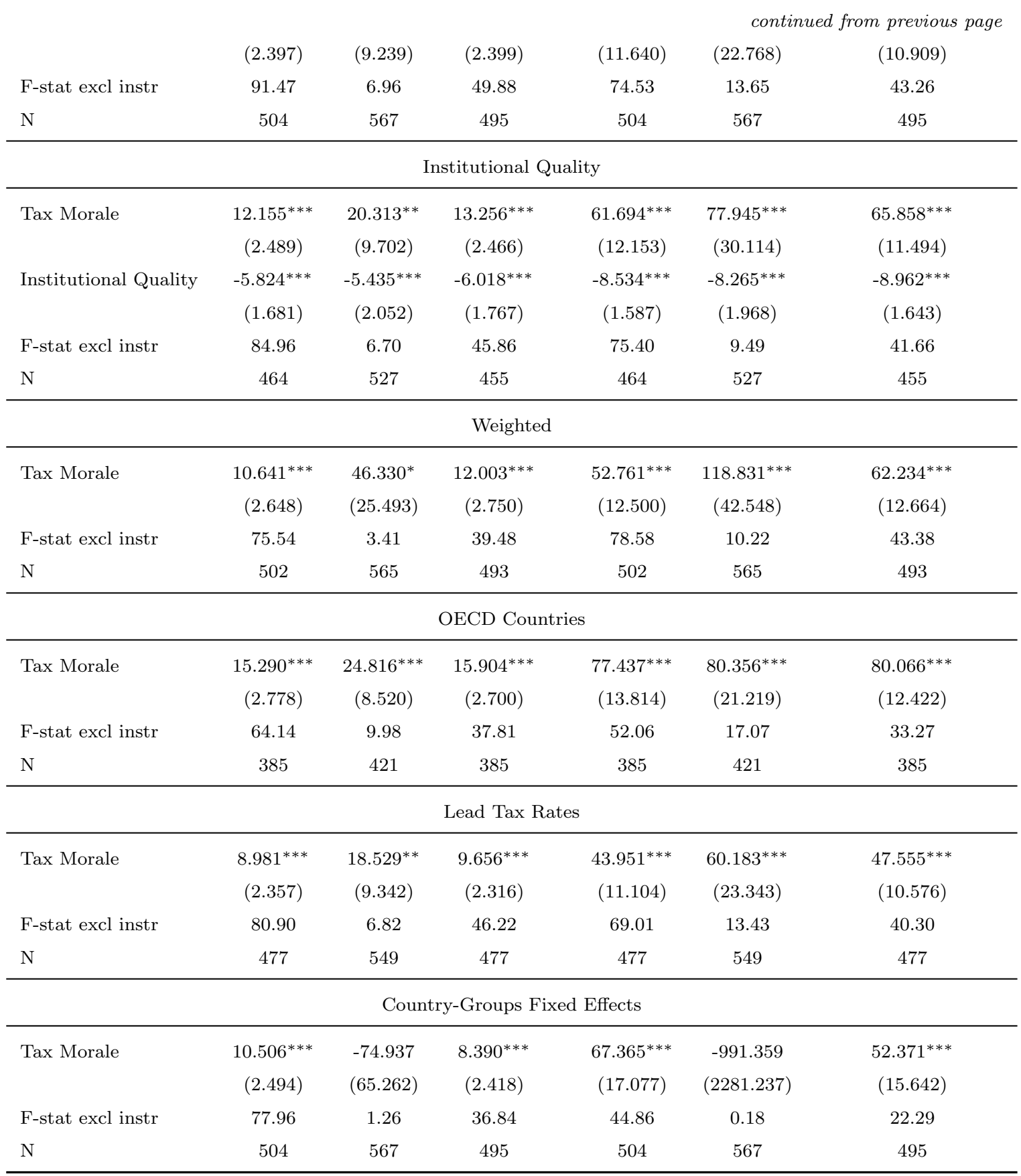

[1] Dep. Var. AR [2] 2SLS IV estimations [3] Cluster-adjusted standard errors [4] All estimations include same control variables as in baseline specifications. [5] Country-Group Fixed Effects contain dummies for regional country groups. [6] Lead tax rates estimations are IV regressions of tax rates in year $t+1$ on tax morale in $t$. [7] Weighted IV regressions weight income groups with the number of individuals in each respective group $[8] *<0.10, * *<0.05, * * *<0.01$

We are able to confirm our baseline results in almost all sensitivity checks. Tax rates, ceteris paribus, depend positively on the level of tax morale and the results are mostly significantly different from zero. In most specifications, the size 
of the tax morale point estimates is roughly similar to the sizes in the baseline. Interestingly, when the sample is restricted to OECD countries, we find significant point estimates that are slightly larger than in the baseline scenario. Additionally, we confirm Brennan and Buchanan's (1980) argument of a negative relationship between tax rates and the quality of bureaucracy.

\section{Conclusion}

In this paper, we construct an international panel dataset of (average and marginal) tax rates and tax morale parameters in order to provide evidence of the relationship between tax morale and the tax burden imposed on different income groups. We set up a simple model of Ramsey-type optimal income taxation where different groups of taxpayers face different subjective costs of evading taxes. The model shows that the tax rate imposed on a group will be higher, the higher the group's tax morale, i.e., the less responsive tax base will be taxed at higher rates. Using data from the EVS/WVS and the WTI and based on an IV approach, we find empirical support for this hypothesis. Our results show that 'nice guys finish last', i.e., groups with higher tax morale have to bear a higher tax burden. Several robustness checks validate our baseline results.

From the government's perspective, this distribution of taxes is efficient because the costs of taxation - caused by distortions - are smaller for individuals with a

high tax morale. Our paper therefore relates to the growing literature on elasticities of taxable income (Feldstein 1999; Saez et al. 2011). If the tax morale parameter is interpreted as a proxy for the tax evasion elasticity, our empirical results show that the actual distribution of tax burdens is indeed associated with these elasticities, i.e., that governments take this information into account when designing actual tax systems. This provides an empirical test of the inverse elasticity rule of optimal taxation, which is another contribution of our paper.

Our findings also shed new light on the growing literature on tax morale. So far, scholars have mostly argued that a high general level of tax morale is advantageous for a society because it increases the efficiency of a tax system. Many empirical studies have worked out possible determinants of tax morale and derived the policy implication that strengthening these determinants helps to increase tax morale and therefore the efficiency of raising taxes. While we do not contradict this view, we show that governments already seem to exploit high relative levels of tax morale among particular groups and, ceteris paribus, tax them higher than low morale groups in the same country. The welfare implications of this finding are, however, 
less clear. Despite being taxed more heavily, such a policy might still be welfare improving even for high morale groups if they receive some kind of 'warm glow' effect due to the intrinsic satisfaction of doing the right thing when complying with the tax law. It would also be interesting to extend the analysis to allow for endogenous levels of tax morale (see, e.g., Traxler 2010, who incorporates tax morale endogenously into the standard model of tax evasion). A tax policy as sketched in our study is likely to be self defeating in the long term in that it creates incentives to develop a lower level of tax morale. Exploring this is a topic for future research. 


\section{A Appendix}

\section{A.1 Summary Statistics}

Table 5: Summary statistics

\begin{tabular}{lccc}
\hline \hline \multicolumn{1}{c}{ Variable } & Mean & Std. Dev. & $\mathbf{N}$ \\
\hline Average Tax Rate (AR) & 24.191 & 15.243 & 694 \\
Marginal Tax Rate (MR) & 30.483 & 15.179 & 693 \\
AR lead & 24.483 & 15.584 & 650 \\
MR lead & 30.619 & 15.3 & 649 \\
Tax morale index & 8.420 & 0.863 & 685 \\
Tax morale dummy & 0.562 & 0.179 & 685 \\
Cheat public transp & 8.424 & 0.846 & 606 \\
Unself imp for child & 0.31 & 0.171 & 692 \\
Full time & 0.718 & 0.172 & 701 \\
Part time & 0.125 & 0.097 & 701 \\
Self employed & 0.157 & 0.159 & 701 \\
Single & 0.287 & 0.141 & 701 \\
Married & 0.637 & 0.171 & 701 \\
Divorced & 0.052 & 0.074 & 701 \\
Widowed & 0.023 & 0.041 & 701 \\
Age & 38.99 & 3.776 & 701 \\
Number children & 1.758 & 0.559 & 692 \\
Age at compl educ & 19.408 & 3.299 & 598 \\
Church once month & 0.336 & 0.24 & 686 \\
GDP per cap, ppp & 18.453 & 11.142 & 701 \\
GDP growth & 2.82 & 3.463 & 701 \\
FDI, net inflows & 11.018 & 63.623 & 701 \\
Institutional quality & 3.089 & 0.933 & 624 \\
\hline \hline
\end{tabular}

Table 6: Means of key variables by country and year

\begin{tabular}{lllllllll}
\hline \hline Country & Year & Group & TM-10 & TM & AR & MR & cheat & unself \\
\hline Albania & 2002 & East Eur & 9.079 & 0.587 & 17.672 & 21.972 & 8.583 & 0.134 \\
Australia & 1995 & Anglo & 8.616 & 0.563 & 44.611 & 46.441 & 8.819 & 0.400 \\
Australia & 2005 & Anglo & 8.701 & 0.546 & 23.058 & 33.248 & 8.361 & 0.502 \\
Austria & 1999 & Cont Eur & 8.687 & 0.553 & 21.224 & 33.229 & 8.509 & 0.042 \\
Belgium & \multirow{2}{*}{1990} & Cont Eur & 6.290 & 0.261 & 24.841 & 39.387 & 8.217 & 0.272 \\
& & & & & & & & continues on next page
\end{tabular}




\begin{tabular}{|c|c|c|c|}
\hline Belgium & 1999 & Cont Eur & 6.941 \\
\hline Brazil & 1990 & Latin & 7.813 \\
\hline Bulgaria & 1999 & East Eur & 8.804 \\
\hline Belarus & 1996 & Soviet & 7.362 \\
\hline Canada & 1982 & Anglo & 8.920 \\
\hline Canada & 1990 & Anglo & 8.437 \\
\hline Canada & 2000 & Anglo & 8.886 \\
\hline Canada & 2006 & Anglo & 9.116 \\
\hline Chile & 1990 & Latin & 9.121 \\
\hline Chile & 1996 & Latin & 8.818 \\
\hline Chile & 2000 & Latin & 8.726 \\
\hline Croatia & 1996 & East Eur & 7.110 \\
\hline Croatia & 1999 & East Eur & 8.187 \\
\hline Czech Republic & 1999 & East Eur & 8.785 \\
\hline Denmark & 1981 & Scand & 8.436 \\
\hline Denmark & 1999 & Scand & 8.795 \\
\hline Estonia & 1996 & East Eur & 7.231 \\
\hline Estonia & 1999 & Soviet & 7.605 \\
\hline Finland & 1990 & Scand & 7.542 \\
\hline Finland & 2005 & Scand & 8.715 \\
\hline France & 1999 & Cont Eur & 7.599 \\
\hline Germany & 1990 & Cont Eur & 8.267 \\
\hline Hungary & 1991 & East Eur & 7.682 \\
\hline Iceland & 1984 & Scand & 8.570 \\
\hline India & 1990 & Asia & 9.439 \\
\hline India & 2001 & Asia & 9.126 \\
\hline Ireland & 1990 & Anglo & 8.045 \\
\hline Israel & 2001 & Cont Eur & . \\
\hline Italy & 1990 & Cont Eur & 7.647 \\
\hline Italy & 1999 & Cont Eur & 8.572 \\
\hline Italy & 2005 & Cont Eur & 8.415 \\
\hline Japan & 1990 & Asia & 9.541 \\
\hline Japan & 1995 & Asia & 9.504 \\
\hline Japan & 2000 & Asia & 9.527 \\
\hline Japan & 2005 & Asia & 9.390 \\
\hline Korea & 1996 & Asia & 9.177 \\
\hline Latvia & 1999 & Soviet & 7.946 \\
\hline Lithuania & 1997 & Soviet & 7.590 \\
\hline Lithuania & 1999 & Soviet & 7.278 \\
\hline Luxembourg & 1999 & Cont Eur & 7.792 \\
\hline Malta & 1999 & Cont Eur & 9.238 \\
\hline Mexico & 2000 & Latin & 8.666 \\
\hline Mexico & 2005 & Latin & 8.746 \\
\hline Morocco & 2001 & Develop & 9.578 \\
\hline Netherlands & 1981 & Cont Eur & 7.701 \\
\hline Netherlands & 1990 & Cont Eur & 7.771 \\
\hline
\end{tabular}

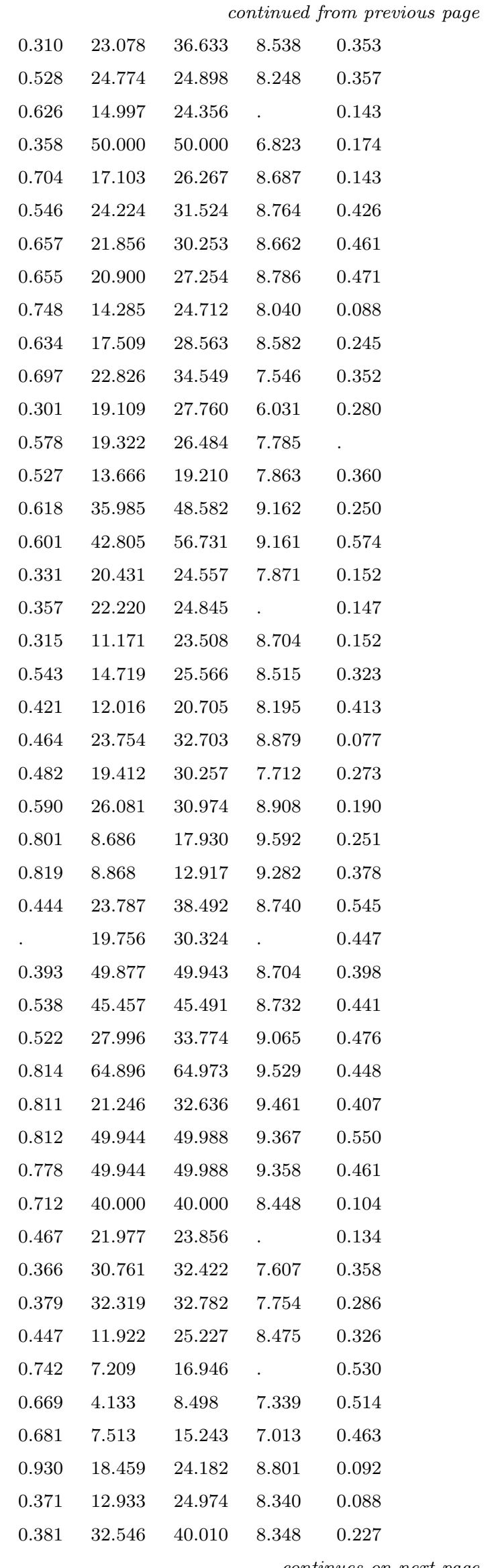




\begin{tabular}{|c|c|c|c|c|c|c|c|c|}
\hline \multirow[b]{2}{*}{ New Zealand } & \multirow[b]{2}{*}{1998} & \multirow[b]{2}{*}{ Anglo } & \multirow[b]{2}{*}{8.697} & \multirow[b]{2}{*}{0.583} & \multicolumn{4}{|c|}{ continued from previous page } \\
\hline & & & & & 31.881 & 32.720 & 8.985 & 0.358 \\
\hline Nigeria & 1990 & Develop & 8.683 & 0.614 & 37.634 & 43.428 & 8.476 & 0.176 \\
\hline Norway & 1996 & Scand & 8.196 & 0.458 & 25.411 & 34.634 & 9.134 & 0.108 \\
\hline Peru & 1996 & Latin & 8.759 & 0.625 & 5.046 & 8.316 & 8.083 & 0.174 \\
\hline Peru & 2001 & Latin & 8.900 & 0.673 & 3.781 & 6.563 & 8.477 & 0.467 \\
\hline Peru & 2006 & Latin & . & . & 3.313 & 5.743 & . & 0.747 \\
\hline Portugal & 1990 & Cont Eur & 7.403 & 0.375 & 39.944 & 39.980 & 8.325 & 0.304 \\
\hline Romania & 1998 & East Eur & 8.471 & 0.613 & 44.999 & 44.999 & 8.714 & 0.386 \\
\hline Russia & 1996 & Soviet & 7.181 & 0.382 & 35.000 & 35.000 & 6.937 & 0.196 \\
\hline Slovakia & 1998 & East Eur & 7.529 & 0.327 & 16.988 & 23.783 & 7.189 & 0.191 \\
\hline Slovakia & 1999 & East Eur & 8.898 & 0.602 & 15.539 & 22.375 & . & 0.203 \\
\hline Slovenia & 1999 & East Eur & 8.515 & 0.568 & 22.756 & 30.034 & & 0.398 \\
\hline South Africa & 1990 & Develop & 8.518 & 0.616 & 16.450 & 25.588 & . & 0.203 \\
\hline South Africa & 1996 & Develop & 8.889 & 0.706 & 22.405 & 33.542 & 9.095 & 0.247 \\
\hline South Africa & 2001 & Develop & 8.755 & 0.598 & 14.575 & 21.494 & 8.774 & 0.315 \\
\hline Spain & 1981 & Cont Eur & 7.858 & 0.445 & 40.000 & 40.000 & 8.478 & 0.038 \\
\hline Spain & 1990 & Cont Eur & 7.898 & 0.475 & 14.195 & 22.927 & 8.408 & 0.081 \\
\hline Spain & 1995 & Cont Eur & 8.652 & 0.654 & 55.872 & 55.957 & 8.703 & 0.174 \\
\hline Sweden & 1996 & Scand & 8.297 & 0.459 & 8.695 & 19.398 & 8.025 & 0.259 \\
\hline Sweden & 2006 & Scand & 8.466 & 0.478 & 4.884 & 15.316 & 8.058 & 0.333 \\
\hline Sweden & 1999 & Scand & 8.423 & 0.469 & 6.889 & 17.085 & . & 0.330 \\
\hline Switzerland & 1989 & Cont Eur & 8.269 & 0.567 & 16.626 & 25.341 & 9.145 & 0.397 \\
\hline Turkey & 1990 & Develop & 9.608 & 0.756 & 49.780 & 49.884 & 8.220 & 0.277 \\
\hline Turkey & 2001 & Develop & 9.630 & 0.882 & 39.998 & 39.999 & . & 0.296 \\
\hline Uganda & 2001 & Develop & 7.802 & 0.611 & 29.961 & 29.982 & 8.439 & 0.172 \\
\hline United Kingdom & 1990 & Anglo & 8.231 & 0.471 & 15.011 & 21.664 & 8.670 & 0.592 \\
\hline United States & 1990 & Anglo & 9.010 & 0.654 & 13.390 & 19.146 & 8.688 & 0.421 \\
\hline United States & 2000 & Anglo & 8.661 & 0.591 & 15.049 & 22.008 & 8.375 & 0.386 \\
\hline Venezuela & 2000 & Latin & 9.291 & 0.738 & 33.973 & 33.994 & 8.460 & 0.525 \\
\hline
\end{tabular}

Abbreviations: TM-10: Tax morale index, TM: Tax morale dummy, AR: Average tax rate, MR: marginal tax rate, cheat: Cheating on public transportation, unself: Unselfishness important for child,

Anglo: Anglo-Saxon plus AUS and NZ, Cont Eur: Continental Europe plus Israel, Scand:

Scandinavia, East Eur: Eastern Central Europe, Soviet: Former Soviet countries, Latin: Latin

America, Asia: Asia, Develop: Developing countries

\section{A.2 OLS results}

Table 7: OLS Estimations of Tax Morale on Tax Rates

\begin{tabular}{lcccccc}
\hline \hline Independent Variable & \multicolumn{2}{c}{ Tax Morale Ten } & & \multicolumn{2}{c}{ Tax Morale Bi } \\
\cline { 2 - 3 } \cline { 5 - 6 } Dependent Variable & $A R$ & $M R$ & & & $A R$ & $M R$ \\
\hline Tax morale & 1.260 & 1.041 & & & $12.968^{* * *}$ & $11.269^{* * *}$ \\
& & & & & continues on next page
\end{tabular}




\begin{tabular}{|c|c|c|c|c|}
\hline & \multirow[b]{2}{*}{$(0.883)$} & \multicolumn{3}{|c|}{ continued from previous page } \\
\hline & & $(0.792)$ & $(4.387)$ & $(3.841)$ \\
\hline \multirow[t]{2}{*}{ Income group 3} & 2.022 & $6.471^{* *}$ & 2.050 & $6.467^{* *}$ \\
\hline & $(3.186)$ & $(3.198)$ & $(3.145)$ & $(3.165)$ \\
\hline \multirow[t]{2}{*}{ Income group 4} & 2.989 & $7.985^{* *}$ & 3.031 & $7.989^{* *}$ \\
\hline & $(3.177)$ & $(3.235)$ & $(3.131)$ & $(3.201)$ \\
\hline \multirow[t]{2}{*}{ Income group 5} & 3.752 & $10.438^{* * *}$ & 3.672 & $10.341^{* * *}$ \\
\hline & $(3.463)$ & $(3.416)$ & $(3.419)$ & $(3.380)$ \\
\hline \multirow[t]{2}{*}{ Income group 6} & $6.037^{*}$ & $14.271^{* * *}$ & $6.013^{*}$ & $14.225^{* * *}$ \\
\hline & $(3.489)$ & $(3.191)$ & $(3.442)$ & $(3.156)$ \\
\hline \multirow[t]{2}{*}{ Income group 7} & $7.851^{* *}$ & $16.386^{* * *}$ & $8.103^{* *}$ & $16.586^{* * *}$ \\
\hline & $(3.500)$ & $(3.232)$ & $(3.425)$ & $(3.169)$ \\
\hline \multirow[t]{2}{*}{ Income group 8} & $9.591^{* * *}$ & $18.142^{* * *}$ & $9.871^{* * *}$ & $18.372^{* * *}$ \\
\hline & $(3.402)$ & $(3.260)$ & $(3.318)$ & $(3.189)$ \\
\hline \multirow[t]{2}{*}{ Income group 9} & $11.308^{* * *}$ & $19.577^{* * *}$ & $11.520^{* * *}$ & $19.750^{* * *}$ \\
\hline & $(3.609)$ & $(3.358)$ & $(3.513)$ & $(3.275)$ \\
\hline \multirow[t]{2}{*}{ Income group 10} & $13.182^{* * *}$ & $21.182^{* * *}$ & $13.514^{* * *}$ & $21.469^{* * *}$ \\
\hline & $(3.644)$ & $(3.424)$ & $(3.515)$ & $(3.324)$ \\
\hline \multirow[t]{2}{*}{ GDP per capita, PPP } & $0.382^{* * *}$ & $0.422^{* * *}$ & $0.402^{* * *}$ & $0.439 * * *$ \\
\hline & $(0.076)$ & $(0.076)$ & $(0.079)$ & $(0.078)$ \\
\hline \multirow[t]{2}{*}{ GDP growth } & -0.074 & 0.122 & -0.078 & 0.118 \\
\hline & $(0.178)$ & $(0.170)$ & $(0.179)$ & $(0.169)$ \\
\hline \multirow[t]{2}{*}{ FDI, net inflows } & $-0.046^{* * *}$ & $-0.036^{* * *}$ & $-0.045^{* * *}$ & $-0.036^{* * *}$ \\
\hline & $(0.006)$ & $(0.006)$ & $(0.006)$ & $(0.006)$ \\
\hline \multirow[t]{2}{*}{ Constant } & 12.011 & 8.983 & $14.796^{*}$ & 11.054 \\
\hline & $(11.081)$ & $(9.250)$ & $(8.620)$ & $(7.325)$ \\
\hline $\mathrm{N}$ & 576 & 575 & 576 & 575 \\
\hline$R^{2}$ & 0.288 & 0.422 & 0.300 & 0.431 \\
\hline \multicolumn{5}{|c|}{ [1] Dependent variables are average $(\mathrm{AR})$ and marginal $(\mathrm{MR})$ tax rates } \\
\hline \multicolumn{5}{|c|}{ [2] Estimation is by OLS with clustered standard errors. [3] Sociodemographic } \\
\hline \multicolumn{5}{|c|}{ [4] controls and wave dummies are included but not displayed. [5] Income group } \\
\hline \multicolumn{5}{|c|}{2 is reference category. $[6] *<0.10, * *<0.05, * * *<0.01$} \\
\hline
\end{tabular}

\section{A.3 First stage results}

Table 8: First stage results for Table 1

\begin{tabular}{|c|c|c|c|c|c|c|}
\hline \multirow{2}{*}{$\begin{array}{l}\text { Dependent Variable } \\
\text { Excluded IV }\end{array}$} & \multicolumn{3}{|c|}{ Tax Morale Index } & \multicolumn{3}{|c|}{ Tax Morale Dummy } \\
\hline & Cheat & Unself & Both & Cheat & Unself & Both \\
\hline \multirow[t]{2}{*}{ cheat on pub transp } & $0.543^{* * *}$ & & $0.538^{* * *}$ & $0.110^{* * *}$ & & $0.110^{* * *}$ \\
\hline & $(0.057)$ & & $(0.057)$ & $(0.013)$ & & $(0.013)$ \\
\hline \multirow[t]{2}{*}{ unself imp for child } & & $0.595^{* * *}$ & $0.457^{* *}$ & & $0.186^{* * *}$ & $0.141^{* * *}$ \\
\hline & & $(0.225)$ & $(0.231)$ & & $(0.050)$ & $(0.050)$ \\
\hline
\end{tabular}




\begin{tabular}{|c|c|c|c|c|c|c|}
\hline \multirow[b]{2}{*}{ Income group 3} & \multirow[b]{2}{*}{0.105} & \multirow[b]{2}{*}{0.101} & \multirow[b]{2}{*}{0.108} & \multicolumn{3}{|c|}{ continued from previous page } \\
\hline & & & & 0.000 & 0.007 & 0.000 \\
\hline & $(0.149)$ & $(0.171)$ & $(0.150)$ & $(0.033)$ & $(0.037)$ & $(0.032)$ \\
\hline \multirow[t]{2}{*}{ Income group 4} & 0.098 & 0.154 & 0.101 & -0.007 & 0.010 & -0.007 \\
\hline & $(0.157)$ & $(0.178)$ & $(0.160)$ & $(0.033)$ & $(0.037)$ & $(0.033)$ \\
\hline \multirow[t]{2}{*}{ Income group 5} & 0.006 & 0.109 & 0.022 & -0.009 & 0.017 & -0.005 \\
\hline & $(0.155)$ & $(0.176)$ & $(0.158)$ & $(0.034)$ & $(0.038)$ & $(0.035)$ \\
\hline \multirow[t]{2}{*}{ Income group 6} & -0.047 & 0.067 & -0.035 & -0.023 & 0.008 & -0.020 \\
\hline & $(0.163)$ & $(0.186)$ & $(0.166)$ & $(0.035)$ & $(0.040)$ & $(0.036)$ \\
\hline \multirow[t]{2}{*}{ Income group 7} & -0.108 & -0.008 & -0.075 & -0.045 & -0.018 & -0.037 \\
\hline & $(0.184)$ & $(0.202)$ & $(0.189)$ & $(0.040)$ & $(0.044)$ & $(0.041)$ \\
\hline \multirow[t]{2}{*}{ Income group 8} & -0.165 & -0.080 & -0.143 & -0.052 & -0.029 & -0.046 \\
\hline & $(0.171)$ & $(0.196)$ & $(0.175)$ & $(0.037)$ & $(0.042)$ & $(0.038)$ \\
\hline \multirow[t]{2}{*}{ Income group 9} & -0.231 & -0.104 & -0.199 & -0.057 & -0.028 & -0.054 \\
\hline & $(0.188)$ & $(0.210)$ & $(0.190)$ & $(0.043)$ & $(0.047)$ & $(0.043)$ \\
\hline \multirow[t]{2}{*}{ Income group 10} & -0.237 & -0.321 & -0.246 & -0.046 & -0.061 & -0.048 \\
\hline & $(0.192)$ & $(0.220)$ & $(0.194)$ & $(0.042)$ & $(0.048)$ & $(0.042)$ \\
\hline \multirow[t]{2}{*}{ GDP per capita } & $-0.011^{*}$ & -0.002 & $-0.012^{*}$ & $-0.004^{* * *}$ & $-0.002^{* *}$ & $-0.005^{* * *}$ \\
\hline & $(0.006)$ & $(0.005)$ & $(0.006)$ & $(0.001)$ & $(0.001)$ & $(0.001)$ \\
\hline \multirow[t]{2}{*}{ GDP growth } & 0.018 & $0.021^{*}$ & $0.021^{*}$ & 0.002 & 0.003 & 0.003 \\
\hline & $(0.011)$ & $(0.011)$ & $(0.012)$ & $(0.002)$ & $(0.003)$ & $(0.003)$ \\
\hline \multirow[t]{2}{*}{ FDI, net inflows } & $-0.001^{* *}$ & $-0.002^{* * *}$ & $-0.001^{* *}$ & -0.000 & $-0.000^{* *}$ & -0.000 \\
\hline & $(0.000)$ & $(0.000)$ & $(0.000)$ & $(0.000)$ & $(0.000)$ & $(0.000)$ \\
\hline \multirow[t]{2}{*}{ constant } & $3.648^{* * *}$ & $7.480^{* * *}$ & $3.806^{* * *}$ & -0.242 & $0.539 * * *$ & -0.214 \\
\hline & $(0.699)$ & $(0.562)$ & $(0.710)$ & $(0.162)$ & $(0.128)$ & $(0.158)$ \\
\hline $\mathrm{N}$ & 504 & 567 & 495 & 504 & 567 & 495 \\
\hline$R^{2}$ & 0.398 & 0.237 & 0.403 & 0.407 & 0.275 & 0.424 \\
\hline F-stat excl. instr & 91.47 & 6.96 & 49.88 & 74.53 & 13.65 & 43.26 \\
\hline
\end{tabular}

[1] 1st stage results [2] OLS [3] Dependent vars: tax morale index or tax morale dummy [4] Cluster-adjusted standard errors [5] Sociodemographic variables and wave dummies included but not displayed [6] Income group 2 is reference category [7] $*<0.10, * *<0.05, * * *<0.01$ [8] Results correspond to second-stage estimations in table 1

[9] Cheating on public transportation and Unselfishness important for child are second-stage exclusion restrictions

Table 9: First stage results for Table 2

\begin{tabular}{|c|c|c|c|c|c|c|}
\hline \multirow{2}{*}{$\begin{array}{l}\text { Dependent Variable } \\
\text { Excluded IV }\end{array}$} & \multicolumn{3}{|c|}{ Tax Morale Index } & \multicolumn{3}{|c|}{ Tax Morale Dummy } \\
\hline & Cheat & Unself & Both & Cheat & Unself & Both \\
\hline \multirow[t]{2}{*}{ cheat on pub transp } & $0.546^{* * *}$ & & $0.542^{* * *}$ & $0.110^{* * *}$ & & $0.110^{* * *}$ \\
\hline & $(0.057)$ & & $(0.057)$ & $(0.013)$ & & $(0.013)$ \\
\hline \multirow[t]{2}{*}{ unself imp for child } & & $0.603^{* * *}$ & $0.475^{* *}$ & & $0.185^{* * *}$ & $0.142^{* * *}$ \\
\hline & & $(0.227)$ & $(0.232)$ & & $(0.051)$ & $(0.050)$ \\
\hline \multirow[t]{2}{*}{ Income group 3} & 0.093 & 0.094 & 0.093 & -0.000 & 0.008 & -0.000 \\
\hline & $(0.152)$ & $(0.173)$ & $(0.152)$ & $(0.033)$ & $(0.037)$ & $(0.033)$ \\
\hline Income group 4 & 0.085 & 0.147 & 0.085 & -0.007 & 0.011 & -0.007 \\
\hline
\end{tabular}




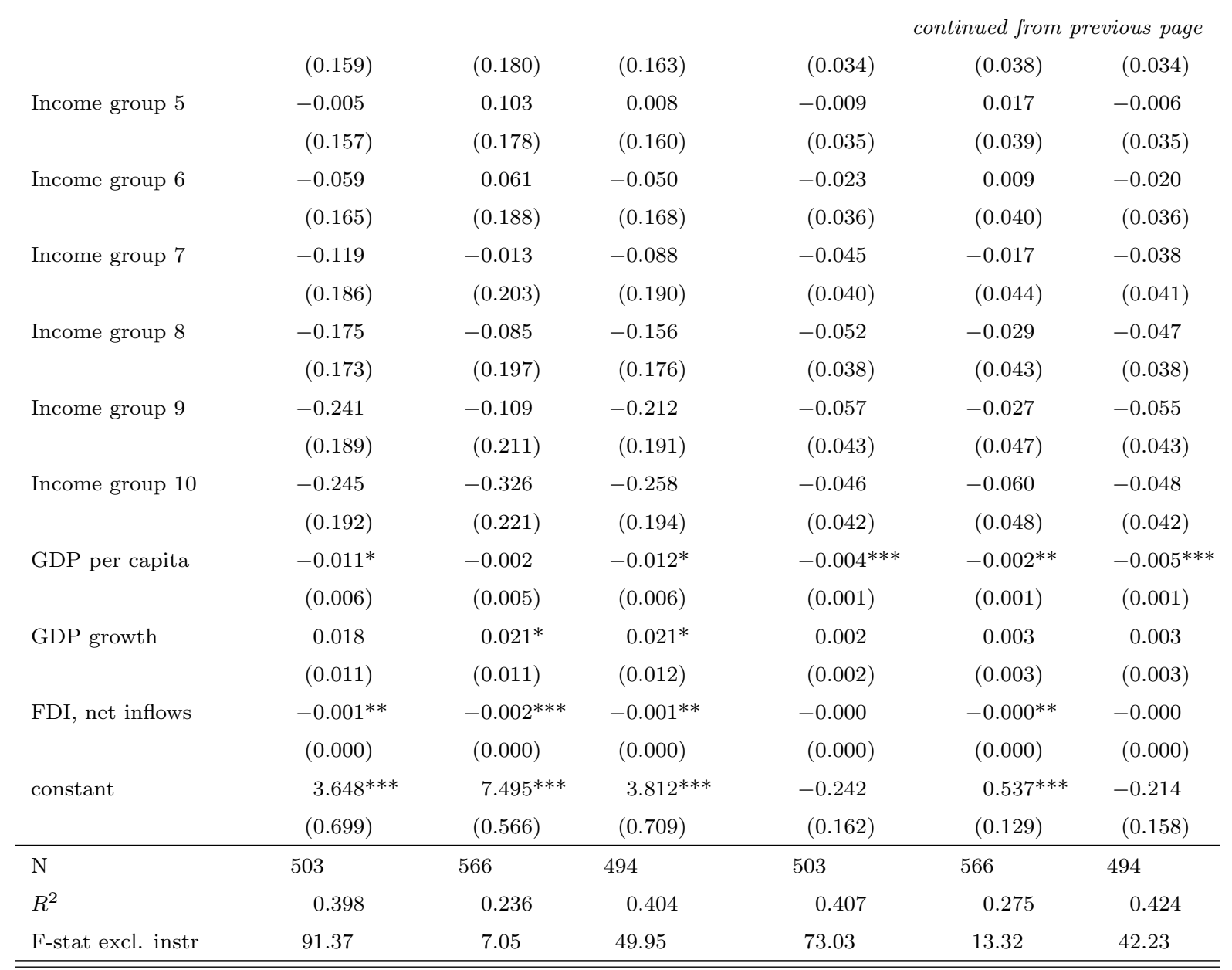

[1] 1st stage results [2] OLS [3] Dependent vars: tax morale index or tax morale dummy [4] Cluster-adjusted standard errors [5] Sociodemographic variables and wave dummies included but not displayed [6] Income group 2 is reference category [7] $*<0.10, * *<0.05, * * *<0.01$ [8] Results correspond to second-stage estimations in table 2

[9] Cheating on public transportation and Unselfishness important for child are second-stage exclusion restrictions

\section{A.4 Sensitivity checks}

Table 10: Sensitivity Checks for Marginal Tax Rate

\begin{tabular}{lccccccc}
\hline \multirow{2}{*}{$\begin{array}{l}\text { Independent Variable } \\
\text { Instrument }\end{array}$} & \multicolumn{3}{c}{ Tax Morale Index } & & \multicolumn{3}{c}{ Tax Morale Dummy } \\
\cline { 2 - 4 } & Cheat & Unself & Both & & Cheat & Unself & Both \\
\hline \multirow{7}{*}{ Tax Morale } & $8.974^{* * *}$ & 10.847 & $9.544^{* * *}$ & & $44.686^{* * *}$ & $35.380^{*}$ & $46.234^{* * *}$ \\
& $(2.206)$ & $(7.053)$ & $(2.209)$ & & $(10.809)$ & $(20.450)$ & $(10.215)$ \\
F-stat excl instr & 91.37 & 7.05 & 49.95 & & 73.03 & 13.32 & 42.23 \\
$\mathrm{~N}$ & 503 & 566 & 494 & & 503 & 566 & 494 \\
\hline
\end{tabular}

Institutional Quality 
continued from previous page

\begin{tabular}{|c|c|c|c|c|c|c|}
\hline \multirow[t]{2}{*}{ Tax Morale } & $9.834^{* * *}$ & 9.125 & $10.329^{* * *}$ & $50.274^{* * *}$ & 35.750 & $51.437^{* * *}$ \\
\hline & $(2.221)$ & $(6.524)$ & $(2.194)$ & $(10.956)$ & $(23.246)$ & $(10.431)$ \\
\hline \multirow[t]{2}{*}{ Institutional Quality } & $-3.059^{*}$ & $-2.900^{*}$ & $-3.142^{*}$ & $-5.260^{* * *}$ & $-4.188^{* * *}$ & $-5.437 * * *$ \\
\hline & $(1.623)$ & $(1.546)$ & $(1.673)$ & $(1.552)$ & $(1.571)$ & $(1.584)$ \\
\hline F-stat excl instr & 84.55 & 6.75 & 45.78 & 73.59 & 9.16 & 40.46 \\
\hline $\mathrm{N}$ & 463 & 526 & 454 & 463 & 526 & 454 \\
\hline \multicolumn{7}{|c|}{ Weighted } \\
\hline \multirow[t]{2}{*}{ Tax Morale } & $8.723^{* * *}$ & 27.046 & $9.661^{* * *}$ & $43.360^{* * *}$ & $70.003^{*}$ & $49.483^{* * *}$ \\
\hline & $(2.777)$ & $(18.470)$ & $(2.852)$ & $(13.190)$ & $(38.050)$ & $(13.194)$ \\
\hline F-stat excl instr & 75.58 & 3.44 & 39.51 & 78.28 & 10.15 & 43.20 \\
\hline $\mathrm{N}$ & 501 & 564 & 492 & 501 & 564 & 492 \\
\hline \multicolumn{7}{|c|}{ OECD Countries } \\
\hline \multirow[t]{2}{*}{ Tax Morale } & $13.332^{* * *}$ & $16.004^{* *}$ & $13.524^{* * *}$ & $68.368^{* * *}$ & $53.158^{* * *}$ & $67.648^{* * *}$ \\
\hline & $(2.566)$ & $(6.779)$ & $(2.522)$ & $(13.234)$ & $(19.446)$ & $(12.265)$ \\
\hline F-stat excl instr & 65.56 & 10.13 & 39.14 & 50.71 & 16.45 & 32.32 \\
\hline $\mathrm{N}$ & 384 & 420 & 384 & 384 & 420 & 384 \\
\hline \multicolumn{7}{|c|}{ Lead Tax Rates } \\
\hline \multirow[t]{2}{*}{ Tax Morale } & $7.998^{* * *}$ & 9.818 & $8.281^{* * *}$ & $39.370^{* * *}$ & 32.515 & $40.375^{* * *}$ \\
\hline & $(2.224)$ & $(7.028)$ & $(2.186)$ & $(10.595)$ & $(20.778)$ & $(10.120)$ \\
\hline F-stat excl instr & 80.71 & 6.91 & 46.23 & 67.57 & 13.10 & 39.31 \\
\hline $\mathrm{N}$ & 476 & 548 & 476 & 476 & 548 & 476 \\
\hline \multicolumn{7}{|c|}{ Country-Group Fixed Effects } \\
\hline \multirow[t]{2}{*}{ Tax Morale } & $8.889^{* * *}$ & -51.757 & $7.555^{* * *}$ & $57.547^{* * *}$ & -630.691 & $46.774^{* * *}$ \\
\hline & $(2.348)$ & $(49.542)$ & $(2.309)$ & $(16.080)$ & $(1414.361)$ & $(15.038)$ \\
\hline F-stat excl instr & 78.40 & 1.17 & 37.10 & 43.94 & 0.19 & 21.83 \\
\hline $\mathrm{N}$ & 503 & 566 & 494 & 503 & 566 & 494 \\
\hline
\end{tabular}

[1] Dep. Var. MR [2] 2SLS IV estimations [3] Cluster-adjusted standard errors [4] All estimations include same control variables as in baseline specifications. [5] Country-Group Fixed-Effects contain dummies for regional country groups. [6] Lead tax rates estimations are IV regressions of tax rates in year $t+1$ on tax morale in t. [7] Weighted IV regressions weight income groups with the number of individuals in each respective group $[8] *<0.10, * *<0.05, * * *<0.01$ 


\section{B An alternative model of tax morale}

We develop a variant of our model of tax morale to show that our key result, that the optimal tax on group $i$ is low if the tax morale of group $i$ is low, does not depend on the particular model used in Section 2. We now assume that differences in tax morale arise for the following reason. There is a critical level of tax evasion denoted by $\bar{e}_{i}$. As long as the undeclared income of an individual of group $i, e_{i}$ is below the critical level $\bar{e}_{i}$, the subjective cost of evading this income is zero. This reflects the idea that a small amount of tax evasion may be seen as morally acceptable. In groups with a high level of tax morale $\bar{e}_{i}$ this 'acceptable' level will be low or even equal to zero, in groups with a lower level of tax morale it may be quite high. If $e_{i} \geq \bar{e}_{i}$, the subjective cost of tax evasion of group $i$ is given by $0.5\left(e-\bar{e}_{i}\right)^{2} \sigma$, where $\sigma$ is a positive tax morale parameter, which does not differ across groups. In this case, the utility function for household $i$ is given by

$$
u_{i}=c_{i}-\frac{1}{2 a_{i}}\left(\frac{y_{i}}{w_{i}}\right)^{2}-\max \left[0,0.5\left(e-\bar{e}_{i}\right)^{2} \sigma\right]
$$

The household's budget constraint is again

$$
c_{i}=y_{i}-t_{i} d_{i}
$$

where $t_{i}$ is the income tax rate. The household chooses gross income $y_{i}$ and declared income $d_{i}$ to maximize utility, subject to the budget constraint. This yields

$$
\begin{aligned}
y_{i}^{*} & =a_{i} w_{i}^{2}\left(1-t_{i}\right), \\
d_{i}^{*} & =a_{i} w_{i}^{2}\left(1-t_{i}\right)-\frac{t_{i}}{\sigma}-\bar{e}_{i} .
\end{aligned}
$$

The optimal tax rate is now given by

$$
t_{i}^{*}=\frac{\left(\eta-b_{i}\right)}{\left(2 \eta-b_{i}\right)} \frac{\left(a_{i} w_{i}^{2}-\overline{e_{i}}\right)}{\left(a_{i} w_{i}^{2}+\frac{1}{\sigma}\right)} .
$$

In this model, tax morale is low if the threshold $\bar{e}_{i}$ is high. Again, the optimal tax rate on groups with low tax morale is lower than that on groups with higher tax morale. 


\section{References}

Allingham, M. G. and A. Sandmo (1972). Income tax evasion: A theoretical analysis. Journal of Public Economics 1(3-4), 323 - 338.

Alm, J. and B. Torgler (2006). Culture differences and tax morale in the United States and in Europe. Journal of Economic Psychology 27(2), 224 - 246.

Andreoni, J., B. Erard, and J. Feinstein (1998). Tax compliance. Journal of Economic Literature 36(2), 818 - 860.

Angrist, J. D., G. W. Imbens, and D. B. Rubin (1996). Identification of causal effects using instrumental variables. Journal of the American Statistical Association 91 (434), $444-455$.

Angrist, J. D. and J. S. Pischke (2009a). Mostly harmless econometrics - An empiricist's companion. Princeton, USA: Princeton University Press.

Angrist, J. D. and J. S. Pischke (2009b). A note on the bias in just identified IV with weak instruments. http://econ.lse.ac.uk/staff/spischke/mhe/ josh/solon_justid_April14.pdf (accessed September 2011).

Barone, G. and S. Mocetti (2011). Tax morale and public spending inefficiency. International Tax and Public Finance. DOI: 10.1007/s10797-011-9174-z.

Bound, J., D. A. Jaeger, and R. M. Baker (1995). Problems with instrumental variables estimation when the correlation between the instruments and the endogeneous explanatory variable is weak. Journal of the American Statistical Association 90(430), $443-450$.

Brennan, G. and J. M. Buchanan (1980). The Power to Tax. Cambridge University Press.

Chetty, R. (2009). Is the taxable income elasticity sufficient to calculate deadweight loss? The implications of evasion and avoidance. American Economic Journal: Economic Policy 1(2), 31 - 52.

Cremer, H. and F. Gahvari (1993). Tax evasion and optimal commodity taxation. Journal of Public Economics 50(2), 261 - 275.

Cummings, R. G., J. Martinez-Vazquez, M. McKee, and B. Torgler (2009). Tax morale affects tax compliance: Evidence from surveys and an artefactual field experiment. Journal of Economic Behavior \& Organization 70(3), 447 - 457.

Doerrenberg, P. and A. Peichl (2011). Progressive taxation and tax morale. Public Choice. DOI: 10.1007/s11127-011-9848-1. 
Elffers, H., R. H. Weigel, and D. J. Hessing (1987). The consequences of different strategies for measuring tax evasion behavior. Journal of Economic Psychology $8(3), 311-337$.

Erard, B. and J. S. Feinstein (1994). The role of moral sentiment and audit perceptions in tax compliance. Public Finance 49 (Supplement), $70-89$.

EVS/WVS (2006). European and World Values Surveys four-wave integrated data file, 1981-2004. Surveys designed and executed by the European Values Study Group and World Values Survey Association. http://worldvaluessurvey . org/ (accessed April 2011).

Feld, L. P. and B. S. Frey (2007). Tax compliance as the result of a psychological tax contract: The role of incentives and responsive regulation. Law $\&$ Policy 29(1), 102 - 120.

Feldstein, M. (1999). Tax avoidance and the deadweight loss of the income tax. Review of Economics and Statistics 81(4), $674-680$.

Frey, B. S. and L. P. Feld (2002). Deterrence and morale in taxation. CESifo Working Paper No. 760.

Frey, B. S. and B. Torgler (2007). Tax morale and conditional cooperation. Journal of Comparative Economics 35(1), 136 - 159.

Halla, M. (2010). Tax morale and compliance behavior: First evidence on a causal link. Johannes Kepler University of Linz Working Paper No. 1066.

Helliwell, J. F. (2003). How's life? Combining individual and national variables to explain subjective well-being. Economic Modelling 20(2), 331 - 360 .

ICRG (2011). International country risk guide, table 3b: Political risk components. http://www.prsgroup.com/prsgroup_shoppingcart/ p-75-icrg-historical-data.aspx (accessed September 2011).

Imbens, G. W. and J. D. Angrist (1994). Identification and estimation of local average treatment effects. Econometrica 62(2), $467-475$.

Inglehart, R. (2000). Codebook for World Values Survey. Ann Arbor, USA: Institute for Social Research.

Inglehart, R. (n.d.). Values change the world. http://worldvaluessurvey.org/ (accessed April 2010).

Jenkins, S., R. V. Burkhauser, S. Feng, and J. Larrimore (2011). Measuring inequality using censored data: a multiple-imputation approach to estimation and inference. Journal Of The Royal Statistical Society Series A 174(1), 63 81. 
Konrad, K. A. and S. Qari (2009). The last refuge of a scoundrel? Patriotism and tax compliance. IZA Discussion paper Series No. 4121 and forthcoming Economica.

Lubian, D. and L. Zarri (2011). Happiness and tax morale: An empirical analysis. Journal of Economic Behavior \& Organization 80(1), 223 - 243.

Mirrlees, J. A. (1971). An exploration in the theory of optimum income taxation. The Review of Economic Studies 38(2), 175 - 208.

Piketty, T., E. Saez, and S. Stantcheva (2011). Optimal taxation of top labor incomes: A tale of three elasticities. mimeo, University of California at Berkeley.

Qari, S., K. A. Konrad, and B. Geys (2011). Patriotism, taxation and international mobility. Public Choice. DOI 10.1007/s11127-011-9765-3.

Ramsey, F. P. (1927). A contribution to the theory of taxation. The Economic Journal $37(145), 47-61$.

Reiter, J. (2003). Inference for partially synthetic, public use microdatasets. Survey Methodology 29(2), $181-188$.

Richardson, G. (2006). Determinants of tax evasion: A cross-country investigation. Journal of International Accounting, Auditing and Taxation 15(2), 150 -169 .

Sabirianova-Peter, K., P. Buttrick, and D. Duncan (2010). Global reform of personal income taxation, 1981-2005: Evidence from 189 countries. National Tax Journal 63(3), $447-478$.

Saez, E. (2001). Using elasticities to derive optimal income tax rates. Review of Economic Studies 68(1), 205 - 229.

Saez, E., J. Slemrod, and S. H. Giertz (2011). The elasticity of taxable income with respect to marginal tax rates: A critical review. Journal of Economic Literature. forthcoming.

Sandmo, A. (1981). Income tax evasion, labour supply, and the equity-efficiency tradeoff. Journal of Public Economics 16(3), 265 - 288.

Schwartz, R. D. and S. Orleans (1967). On legal sanctions. University of Chicago Law review 34, $274-300$.

Sheshinski, E. (1972). The optimal linear income-tax. The Review of Economic Studies 39(3), 297 - 302.

Simonovits, A. (2011). Higher tax morale implies a higher optimal income tax rate. Hungarian Academy of Science, Institute of Economics, Working Paper $2011 / 37$. 
Slemrod, J. (1992). Do taxes matter? Lessons from the 1980's. American Economic Review. Papers and Proceedings 82(2), 250 - 256.

Slemrod, J. (2003). Trust in public finance. In S. Cnossen and H.-W. Sinn (Eds.), Public Finance and Public Policy in the New Century, pp. 49 - 88. Cambridge, USA: The MIT Press.

Slemrod, J. and S. Yitzhaki (2002). Tax avoidance, evasion, and administration. In A. J. Auerbach and M. Feldstein (Eds.), n.a., Volume 3 of Handbook of Public Economics, pp. 1423 - 1470. Amsterdam, Netherlands: Elsevier.

Staiger, D. and J. H. Stock (1997). Instrumental variables regression with weak instruments. Econometrica 65(3), $557-586$.

Torgler, B. (2002). Speaking to theorists and searching for facts: Tax morale and tax compliance in experiments. Journal of Economic Surveys 16(5), 657 683.

Torgler, B. (2006). The importance of faith: Tax morale and religiosity. Journal of Economic Behavior \& Organization 61(1), 81 - 109.

Torgler, B. (2007). Tax Compliance and Tax Morale: A Theoretical and Empirical Analysis. Cheltenham, UK: Edward Elgar.

Torgler, B. and F. Schneider (2007). What shapes attitudes toward paying taxes? Evidence from multicultural European countries. Social Science Quarterly $88(2), 443-470$.

Torgler, B. and F. Schneider (2009). The impact of tax morale and institutional quality on the shadow economy. Journal of Economic Psychology 30(2), 228 -245 .

Traxler, C. (2010). Social norms and conditional cooperative taxpayers. European Journal of Political Economy 26(1), 89 - 103.

World Bank (2010). The Word Development Indicators. http://databank. worldbank.org/ (accessed June 2011).

WVS (2009). European and World Values Surveys 2005 offcial data file v.20090901. http://worldvaluessurvey.org/ (accessed April 2011).

Yitzhaki, S. (1974). A note on income tax evasion: A theoretical analysis. Journal of Public Economics 3(2), 201 - 202. 